Article

\title{
A GHG Metric Methodology to Assess Onsite Buildings Non-Potable Water System for Outdoor Landscape Use
}

\author{
Geraldine Seguela $^{1, *}$, John R. Littlewood ${ }^{1}\left(\mathbb{D}\right.$ and George Karani ${ }^{2}$ \\ 1 The Sustainable \& Resilient Built Environment group, Cardiff School of Art \& Design, Cardiff Metropolitan \\ University, CF5 2YB Cardiff, UK; jlittlewood@cardiffmet.ac.uk \\ 2 The Environmental Public Health Group, Cardiff School of Health Sciences, Cardiff Metropolitan University, \\ CF5 2YB Cardiff, UK; gkarani@cardiffmet.ac.uk \\ * Correspondence: geseguela@cardiffmet.ac.uk; Tel.: +61-421-365-026
}

Received: 20 December 2019; Accepted: 9 February 2020; Published: 16 February 2020

\begin{abstract}
This paper documents a water:energy greenhouse gas (GHG) metric methodology for a decentralized non-potable water system that was developed as part of a Professional Doctorate in Engineering (DEng) research project by the first author. The project identified the need to investigate the challenges in changing the use of potable water to recycled water for landscape irrigation (LI) and for water features (WFs) at a medical facility case study (MFCS) in Abu Dhabi (AD) (the capital city of the United Arab Emirates (UAE). The drivers for the research project were based on the need for $\mathrm{AD}$ to decrease desalinated potable water as well as reduce the environmental impact and operational costs associated with the processing and use of desalinated water. Thus, the aim of the research discussed and presented in this paper was to measure the impact of using recycled and onsite non-potable water sources at the MFCS to alleviate the use of desalinated potable water and reduce associated energy consumption, operational costs, and GHG emissions (latterly in terms of carbon dioxide equivalent $\left(\mathrm{CO}_{2 \mathrm{e}}\right)$, for $\mathrm{LI}$ and WFs. The analysis of three case scenarios at the MFCS compared different approaches to alleviate energy use, costs, and GHG impacts for the use of recycled water in LI and WFs against a baseline. The findings led to a proposed sustainable water conservation and reuse (SWC) strategy, which helped save 50\% desalinated potable water for LI use by soil improvement, building water system audits, and alternate non-potable water reuse. The recommendations for this paper are to develop a SWC strategy forming the basis for a water protocol by the competent authority for regional medical facilities including an assessment methodology for building decentralized non-potable water systems to measure their energy, GHG emissions and financial impact.
\end{abstract}

Keywords: water recycling; landscape irrigation; climates change; greenhouse gas metric; maintenance

\section{Introduction}

\subsection{Research Background}

The climate of the United Arab Emirates (UAE) is classified as Arid (B), Desert (W), and Hot Arid (h) (Bwh) by Köppen and Geiger [1], which makes it a hot desert type climate. The mean yearly temperature, relative humidity (RH), and rainfall for Abu Dhabi (AD) is 27.6 Celsius $\left({ }^{\circ} \mathrm{C}\right), 63 \%$, and $62.1 \mathrm{~mm}(\mathrm{~mm})$, respectively [2]. Still in October 2019, 13 Arab countries were among the world's 19 most water-scarce countries [3,4]. Per capita, water availability in eight Middle East countries is below $200 \mathrm{~m}^{3}$ per year including the UAE [5] (see Figure 1). Therefore, with such an arid climate, there is a 
significant need to investigate and implement all opportunities for recycling and reusing water in the built environment and their associated landscapes in AD.
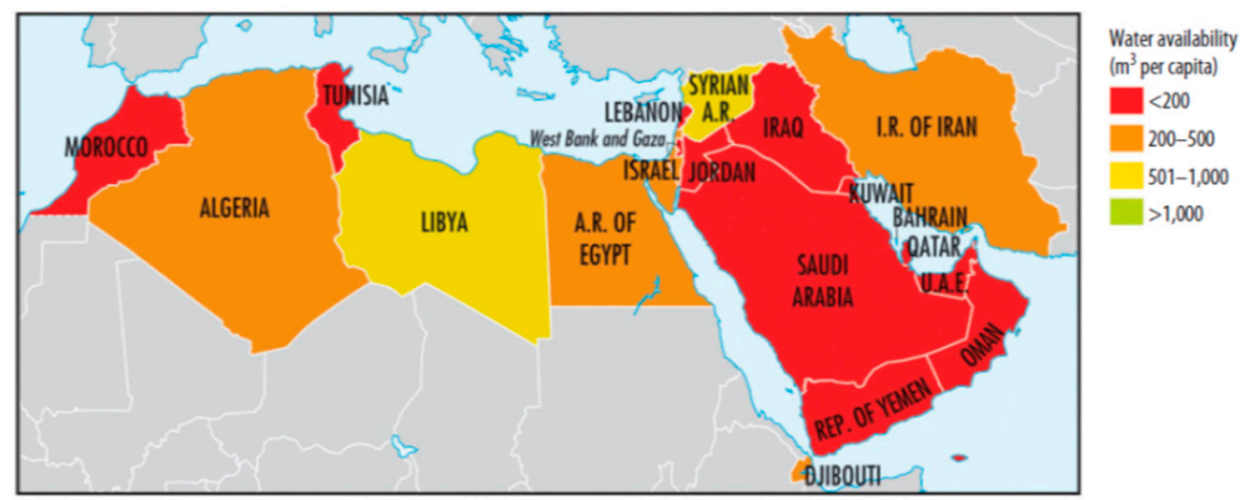

Figure 1. Declining per capita water availability: A growing threat in Middle East North Africa (MENA) [5] in [6].

The medical facility case study (MFCS) was a 364-bedroom hospital that opened in 2015 with 50\% of its footprint dedicated to landscaping $\left(33,354 \mathrm{~m}^{2}\right)$, and the design aspirations were to target $100 \%$ non-clinical/non-potable water use for landscape irrigation (LI) and use in water features (WFs) from treated air conditioning $(\mathrm{A} / \mathrm{C})$ condensate water. Peak condensate formation occurs during the hottest and most humid months of each year (April to November) with the minimum condensate formation rates occurring in the winter and spring months between December and April [7]. This is because the MFCS does not need to be cooled in winter and spring as much as in summer.

Hence, therein lies a problem since for five months per year (December-April) there is a predicted non-potable water deficit and desalinated potable water is required for use in LI and WFs, which is expensive and has significant associated carbon emissions from the desalination process of seawater. Thus, the research set out to investigate any additional sources of water use/harvesting that could be recycled for reuse in LI and WFs at the MFCS to mitigate the use of potable water use during the five months of the year when no treated condensate water is available [6].

In order to investigate alternate sources of water for recycling and reuse, the research project used a mixed methods approach after Creswell and Creswell [8] to collect data on water sources available at the MFCS. The water and energy data were used to develop a sustainable water conservation and reuse (SWC) strategy (that includes the reduction of water consumption for LI by soil improvement, building water system audits, and the use of additional non-potable water sources), forming the basis of a water conservation protocol, thus enabling the MFCS to meet the five-month potable water shortfall. The results also include a greenhouse gas (GHG) metric in terms of kilograms of carbon dioxide equivalent $\left(\mathrm{kgCO}_{2 \mathrm{e}}\right)$ per cubic meter $\left(\mathrm{m}^{3}\right)$ to assess the carbon savings by using recycled water for LI and WFs use.

\subsection{Healthcare Context for Water Conservation}

To the authors' knowledge, there has been no published literature since April 2008 on water research for use in LI or WFs, or energy research related to the healthcare sector [6]. As such, the gap in knowledge that this paper is addressing are non-potable water standards for irrigating landscapes and use in WFs for the healthcare estates in AD, UAE (ibid.). Furthermore, the research discussed is relevant to healthcare estates in climates similar to AD. In the United States of America (USA) in 2002, water consumption ranged from $260 \mathrm{~m}^{3}$ to $1128 \mathrm{~m}^{3}$ per year, per patient bed for hospitals in the size range of 133 to 510 beds [9]. That is, $0.71 \mathrm{~m}^{3}$ and $2.21 \mathrm{~m}^{3}$ per day, per bed respectively. However, a hospital's water use varies widely depending on type, size, geographical location, and water use equipment and practices. The MFCS records indicated an amount of $2.97 \mathrm{~m}^{3}$ of water consumption per patient bed per day (see Figure 2) in $2016\left(395,916 \mathrm{~m}^{3} \div 364\right.$ beds $\div 366$ days), which means that the 
water use for the LI alone in 2016 represented a substantial quantity (36\%) of the total water demand. Thus, a significant opportunity exists to conserve water for outdoor use, whilst at the same time reusing non-potable water for LI and WFs to achieve zero-potable water outdoor use [6].

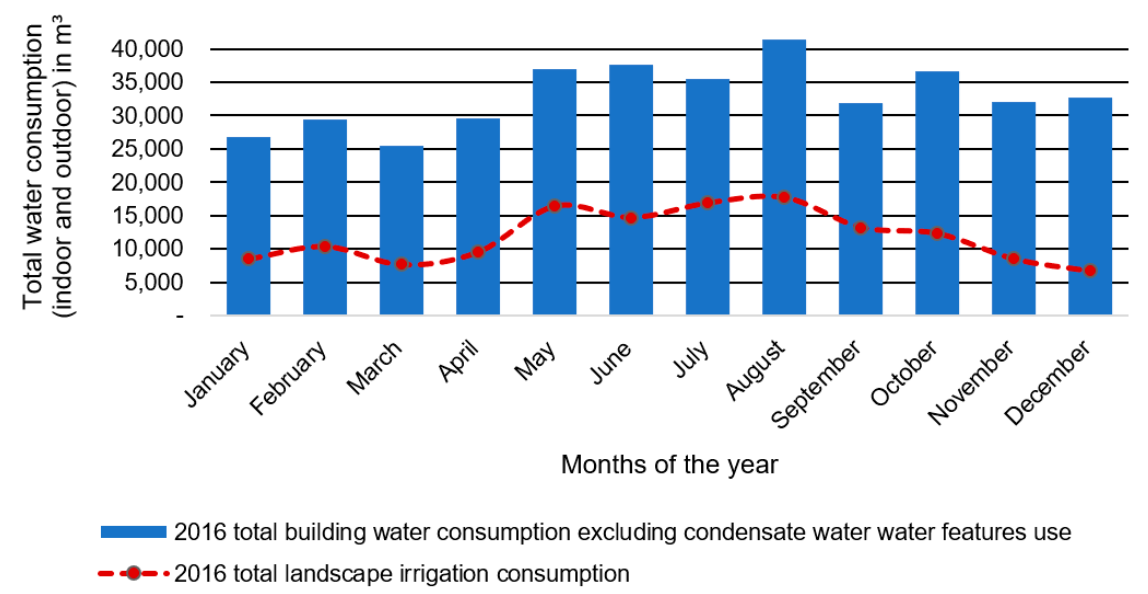

Figure 2. Medical facility case study (MFCS) total building water use against LI consumption based on 2016 Abu Dhabi Distribution Company (ADDC) water bills [6,10].

\subsection{The Context of the Water Energy Nexus in Abu Dhabi}

AD has embarked on a massive United States (US) five-billion-dollar program, based on the aquifer storage and recovery approach [11]. This program is to build capacity so that local aquifers can be used as strategic reserves for desalinated water [12]. The peak demand forecast for water will more than double by 2030 [13]. The Emirate of AD's annual water consumption is estimated to be 2.49 billion $\mathrm{m}^{3}$ and is expected to reach 5.86 billion $\mathrm{m}^{3}$ by 2020 [14].

In the UAE, groundwater has been extracted at over 13 times the annual recharge rate [15] in [16]. However, water use varies between the emirates. In $\mathrm{AD}, 72 \%$ of the groundwater is mainly used for agriculture irrigation, followed by desalination (24\%) in residential and commercial buildings as domestic water. Plus, four percent is used for treated sewage effluent (TSE), residential district cooling, public park LI and in WFs such as fountains, but not for crop cultivation [16]. In 2012, desalinated water demand in AD exceeded local production, where 201.3 million $\mathrm{m}^{3}$ had to be imported from Fujeirah, a northeastern emirate (ibid.).

Different factors have made the UAE dependent on desalination water. First, the increased water demand of a fast-growing population; second, the low (less than $100 \mathrm{~mm} /$ year) average precipitation; third, a very high evaporation rate (two to three $\mathrm{m}^{3}$ per year) (ibid); and fourth, the limited recharge of the groundwater [4,17]. For this reason, $\mathrm{AD}$ has no choice but to supply domestic water from seawater desalination [17] using techniques such as multi effect distillers (MED), reverse osmosis (RO), and multistage flash (MSF) $[18,19]$. The main technology used in the UAE is thermal desalination with MSF (57\%) because it is more energy efficient and can produce higher quality water (ibid.). MED are used at $6 \%$ for desalinating water and RO at 37\% $[19,20]$. However, as shown in Table 1 , the technique of desalination is still highly energy intensive: RO and MSF technologies use between four-kilowatt hour per cubic meter $\left(\mathrm{kWh} / \mathrm{m}^{3}\right)$ to $7.5 \mathrm{kWh} / \mathrm{m}^{3}$ average and up to $15.40 \mathrm{kWh} / \mathrm{m}^{3}$, respectively [20]. In addition, MSF and RO technologies also have a very high cost of 1.10-1.25 United States dollars (USD) per $\mathrm{m}^{3}$ and $0.68-0.82 \mathrm{USD} / \mathrm{m}^{3}$, respectively, in comparison to $0.05 \mathrm{USD} / \mathrm{m}^{3}$ for fresh water sources [21].

The water supplied to AD Island (the location of the MFCS) is produced at the Arabian Power Company (AMPC), Taweelah Asia Power Company (TAPCO), Gulf Total Tractebel Power Company (GTTPC), and Emirates CMS Power Company (ECPC), as detailed in Table 2 [18]. Desalination plants, which mainly use MSF thermal desalination technology $(74 \%)$ consume energy at a rate of $15.40 \mathrm{kWh} / \mathrm{m}^{3}$ [20], bringing the cost of water production between 1.10 to $1.25 \mathrm{USD} / \mathrm{m}^{3}$ (ibid). 
This provides evidence that the value of water production is not tied to the subsidized ( $50 \%$ discount) commercial and residential AD water tariff, which is AED $4.11 / \mathrm{m}^{3}$ [10] after discount, which is equivalent to USD $1.12 / \mathrm{m}^{3}$ [22].

Table 1. Desalination techniques against financial and environmental impacts [20].

\begin{tabular}{cccc}
\hline Description & MSF & MED & RO \\
\hline Water cost production $\left(\mathrm{USD} / \mathrm{m}^{3}\right)$ & $1.10-1.25$ & $0.75-0.85$ & $0.68-0.82$ \\
Energy use $\left(\mathrm{kWh} / \mathrm{m}^{3}\right)$ & 15.40 & 7.5 & $4-7$ \\
Volume of saline feed water per $\mathrm{m}^{3}$ of fresh water & 4 & 3 & $2-2.5$ \\
\hline
\end{tabular}

Table 2. Desalination plants serving AD Island [18].

\begin{tabular}{ccc}
\hline Abu Dhabi Water Supply & Desalination Technique Used & Water Production Share by Company \\
\hline AMPC & MSF & $2 \%$ \\
TAPCO & MSF & $18 \%$ \\
GTTPC & MSF + MDF & $10 \%$ \\
ECPC & MSF & $6 \%$ \\
\hline
\end{tabular}

Desalination plants have been optimized since 1990-2000, although the process efficiency is still under investigation through pilot programs [11] such as an adsorption desalination system producing pure water with no need for fossil fuel use (ibid.). Thus, in 2017, the process of desalination was still highly energy intensive $[13,14,21]$, hence impacting on the natural environment, and contributing ultimately to climate change. As highlighted in Table 1, it takes $4 \mathrm{~m}^{3}$ of saline feed water for the MSF technology to generate $1 \mathrm{~m}^{3}$ of distillate water [20]. Energy consumption and potential effects on the marine environment of brine disposal are the two largest aspects of environmental impact [14,23-26].

Approximately $60 \%$ of the $\mathrm{AD}$ wastewater is planned to be returned to the sewer by 2030 to be recycled for reuse in applications such as irrigation [27] in [28]. This strategy forms part of the AD government's aims to not permit potable water to be utilized for irrigation purposes, and so alleviate stress on the existing water infrastructure [29] in [28]. As such, it will be mandatory to use treated sewage effluent (TSE) for irrigation (ibid.). To date (2019), to the authors' knowledge, there is no TSE infrastructure near the MFCS location, and the timing for this to happen is presently unknown to the community [30] in [28]. The International Energy Agency (IEA) [31] reported that in 2014, almost 10\% of the Middle East's (including AD) electricity consumption was used to extract, distribute, and treat water and wastewater including the use of large quantities of oil equivalent of thermal energy for irrigation pumps and gas in desalination plants (see Figure 3).

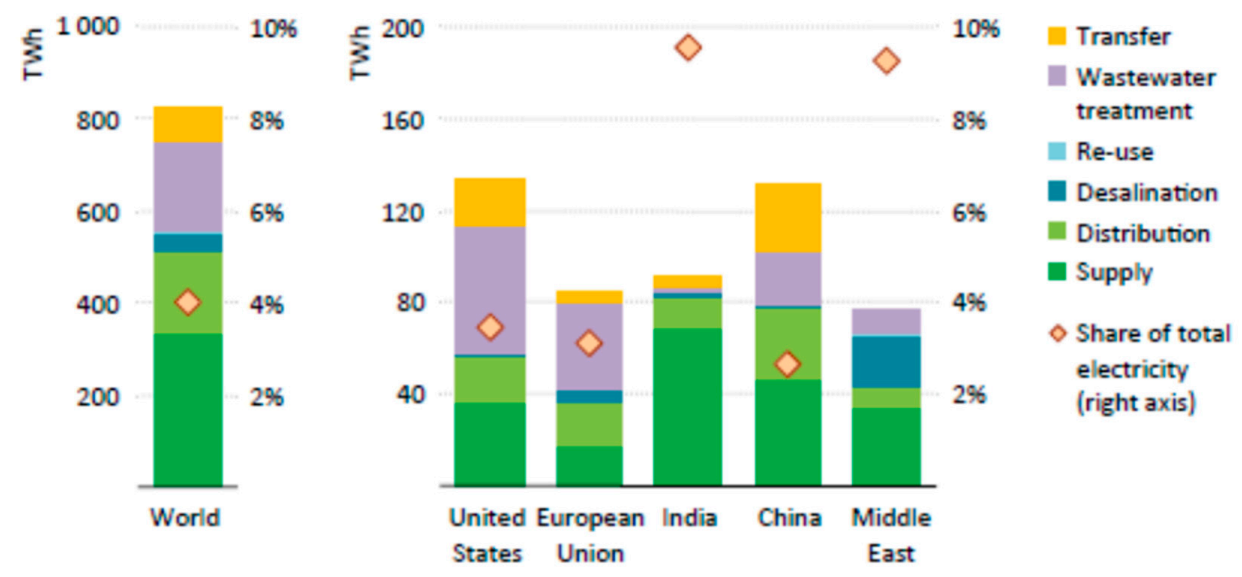

Figure 3. Electricity consumption in the water sector by process and region in 2014 [31]. Supply includes water extraction from groundwater and surface water as well as water treatment. Transfer refers to large-scale inter-basin transfer projects. 
Water systems can save energy by reducing the amount of water that must be withdrawn, treated, and distributed [32], especially in locations like AD, where the technique of desalination is highly energy intensive [20]. Figure 4 illustrates the energy consumption to treat and move water from the source to the end-user $[29,31]$.

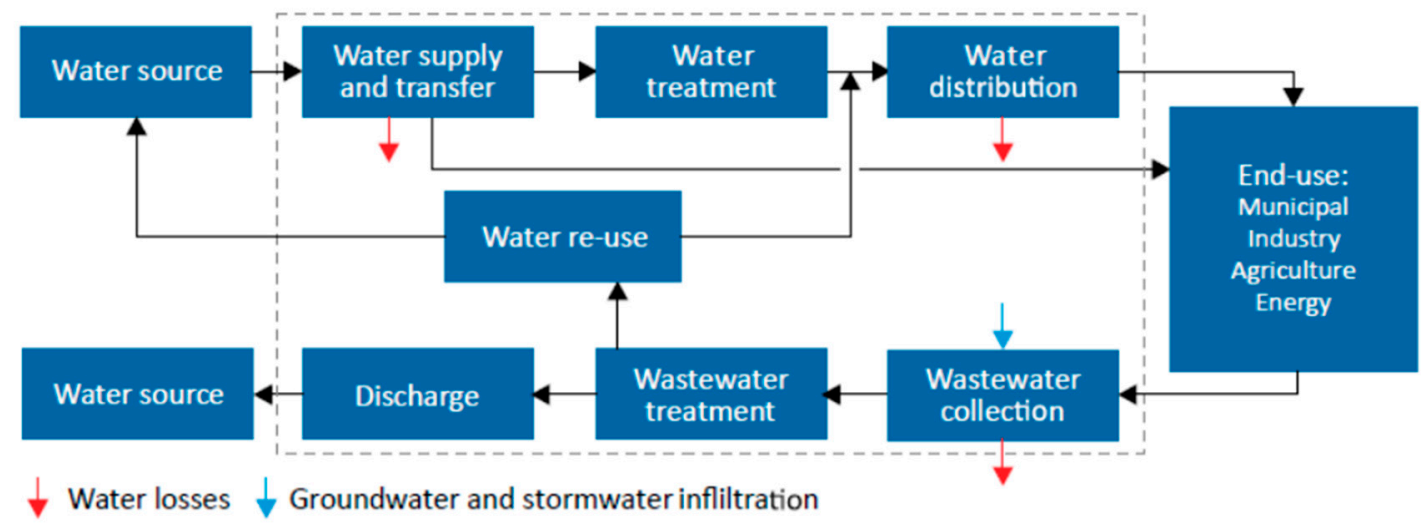

Figure 4. Energy need in each step of the water process [31].

Irrigation is the primary water consumption worldwide [33]. In arid regions where the mean annual precipitation $(\mathrm{P})$ is substantially less than the characteristic potential evapotranspiration (ETo), the appropriate selection of plants and efficient irrigation systems can conserve a great amount of urban irrigation water [34]. In addition, wasting water in sectors such as landscaping in arid regions is further aggravating water scarcity and emphasizing the need to develop ways to improve irrigation efficiency (ibid). This improvement cannot solely depend on improving the efficiency of water pumps without changing the price of electricity or irrigation practices to avoid a water consumption increase and further depletion of aquifers [31].

\subsection{Greenhouse Gas (GHG) Emissions and Decarbonization}

Electricity consumption associated with water and wastewater operations are a major contributor to GHG emissions [35-39]. Internationally recognized GHGs, regulated under the United Nations (UN) Kyoto Protocol [40], linked to the UN Framework Convention on Climate Change (UNFCCC) [41], are composed of long-lived and short-lived GHGs. Long-lived GHGs are mostly $\mathrm{CO}_{2}$ and nitrous oxide $\left(\mathrm{N}_{2} \mathrm{O}\right)$, which can remain in the atmosphere for hundreds of years [42]. Short-lived GHGs are mostly methane $\left(\mathrm{CH}_{4}\right)$, hydrofluorocarbons (HFCs), perfluorocarbons (PFCs), sulfur hexafluoride $\left(\mathrm{SF}_{6}\right)$, and nitrogen trifluoride $\left(\mathrm{NF}_{3}\right)$, and they remain in the atmosphere for much shorter periods, from days to decades [42,43]. Most of the emissions embedded in water are usually from $\mathrm{CO}_{2}, \mathrm{~N}_{2} \mathrm{O}_{\text {, }}$ and $\mathrm{CH}_{4}$ [35]. The level of global warming is determined by the cumulative emissions of $\mathrm{CO}_{2}$ over time and the annual emissions of short-lived GHGs. To stabilize the climate to below 3 degrees Celsius $\left({ }^{\circ} \mathrm{C}\right)$, as stipulated by the UNFCCC [41], carbon neutrality or decarbonization will be needed by 2100 [43]. The energy intensity (responsible for long-lived gases emissions) of the Middle East and Africa region including the UAE increased by 41\% from 1970 to 2010 [44]. The highest key category of GHG emissions in the Emirate of AD comes from the energy industries accounting for 46.8\% [45]. Both the key driver and key category are the consumption of fossil fuels [44,45]. The atmospheric concentration of $\mathrm{CO}_{2}$ keeps increasing as long as emissions are positive, and it decreases if emissions are brought to zero, depending on the cumulative emissions over time. Thus, to stabilize long-lived gas concentrations, both $\mathrm{CO}_{2}$ and $\mathrm{N}_{2} \mathrm{O}$ are required to be brought to zero and short-lived GHGs (CH4, HFCs, PFCs, $\mathrm{SF}_{6}, \mathrm{NF}_{3}$ ) are to be kept constant [43].

In 2019, three water challenges prevail in AD. First, the energy intensity of desalination; second, access to TSE; and third, high irrigation demand. 


\subsection{Gaps Analysis Leading to New Body of Knowledge}

In addition, electricity consumption associated with water and wastewater operations are a major contributor to GHG emissions [35-39]. For GHG emissions embedded in water, most are usually from $\mathrm{CO}_{2}$, methane $\left(\mathrm{CH}_{4}\right)$, and nitrous oxide $\left(\mathrm{N}_{2} \mathrm{O}\right)$ [35]. The energy intensity of non-potable water supply sources (other than desalination water) and decentralized water systems "are unknown and is a knowledge gap that requires further research" [36] as "There is no standardized methodology or framework for the assignment of values to water streams at present" [46]. Additionally, the design of methodologies to account for these GHG emissions have not been transparently available [35]. This knowledge gap is summarized in Table 3.

Table 3. Onsite non-potable water systems for the greenhouse gas (GHG) benchmarking knowledge gap.

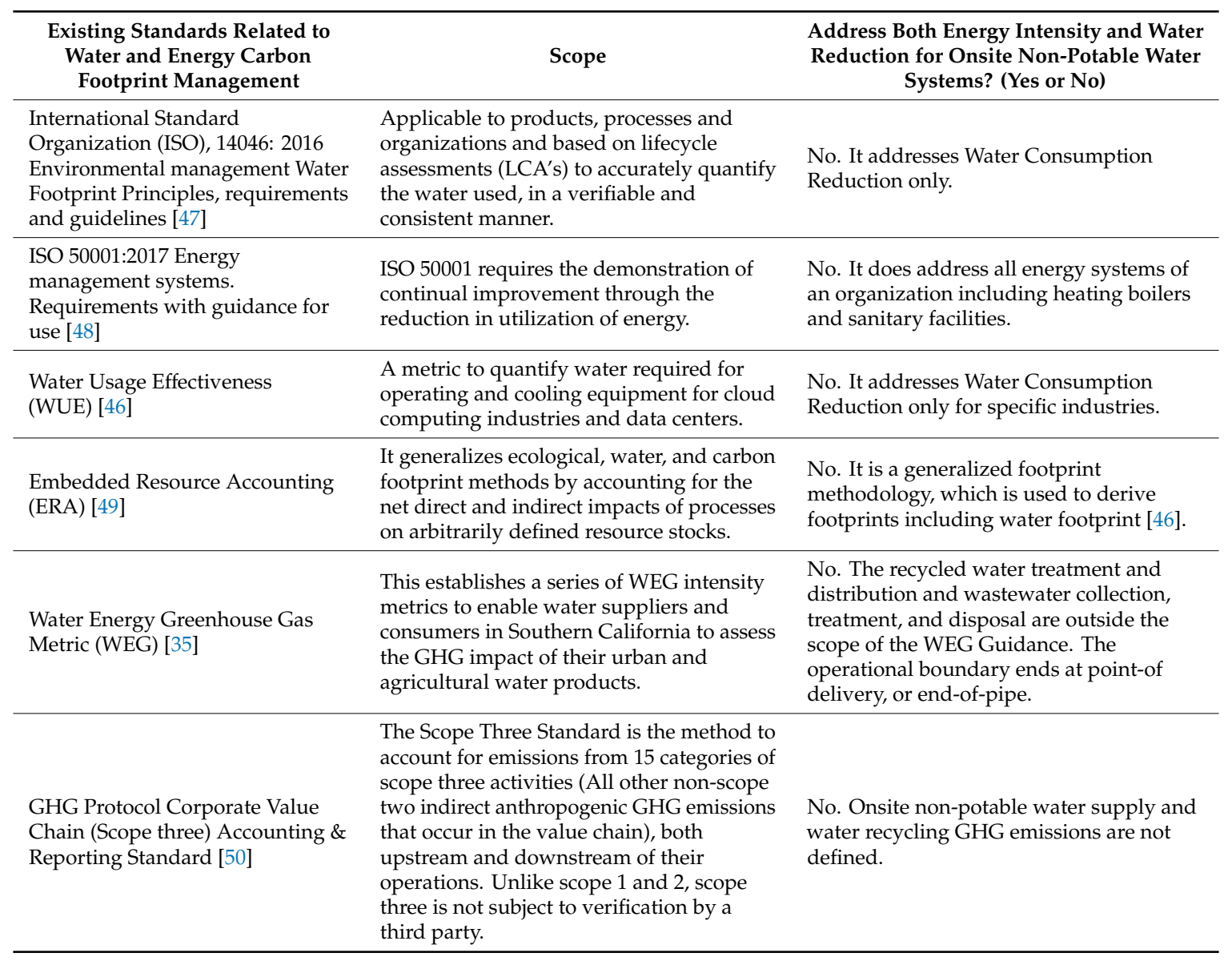

\subsection{Original and Significant Contribution to New Body of Knowledge}

The key original and significant contributions to change in practice from the author's research undertaken as part of her D.Eng. project are to propose a sustainable water conservation and reuse (SWC) strategy forming the basis for a water protocol, specific to arid climate regions such as AD, and which addresses the following. The development of a calculation methodology using equations from the literature to estimate and compare energy consumption in desalinated water and onsite generated non-clinical non-potable water resources for WFs and LI reuse. This is to measure the financial viability through a benefit cost ratio analysis, and to measure the systems' GHG emissions impact with the design and development of a water: energy GHG metric with these units, kilograms of $\mathrm{CO}_{2}$ equivalent per $\mathrm{m}^{3}\left(\mathrm{kgCO}_{2 \mathrm{e}} / \mathrm{m}^{3}\right)$. 


\section{Materials and Methods}

\subsection{A Mixed Method Research}

After initial water usage analysis in 2016 and 2017 through the development of a water balance $[6,28,51,52]$, it was found that the MFCS was wasting large quantities of water, leading to a potential water deficit. For example, the LI was consuming (in January 2018) 46\% more water than the estimated demand based on the Abu Dhabi Municipality (ADM, Abu Dhabi, UAE) standard [53], and after soil improvement. Additionally, the water consumption of the WFs exceeded Seguela et al.'s [51] calculations of the water demand by $80 \%$. Second, the reverse osmosis reject water (RORW) and the fire sprinkler pump test water were deemed suitable to be used as makeup-water to the existing condensate water for LI and WF use, subject to tertiary treatment [6]. Figure 5 illustrates the project research methodology in relation to the impact calculation of the MFCS.
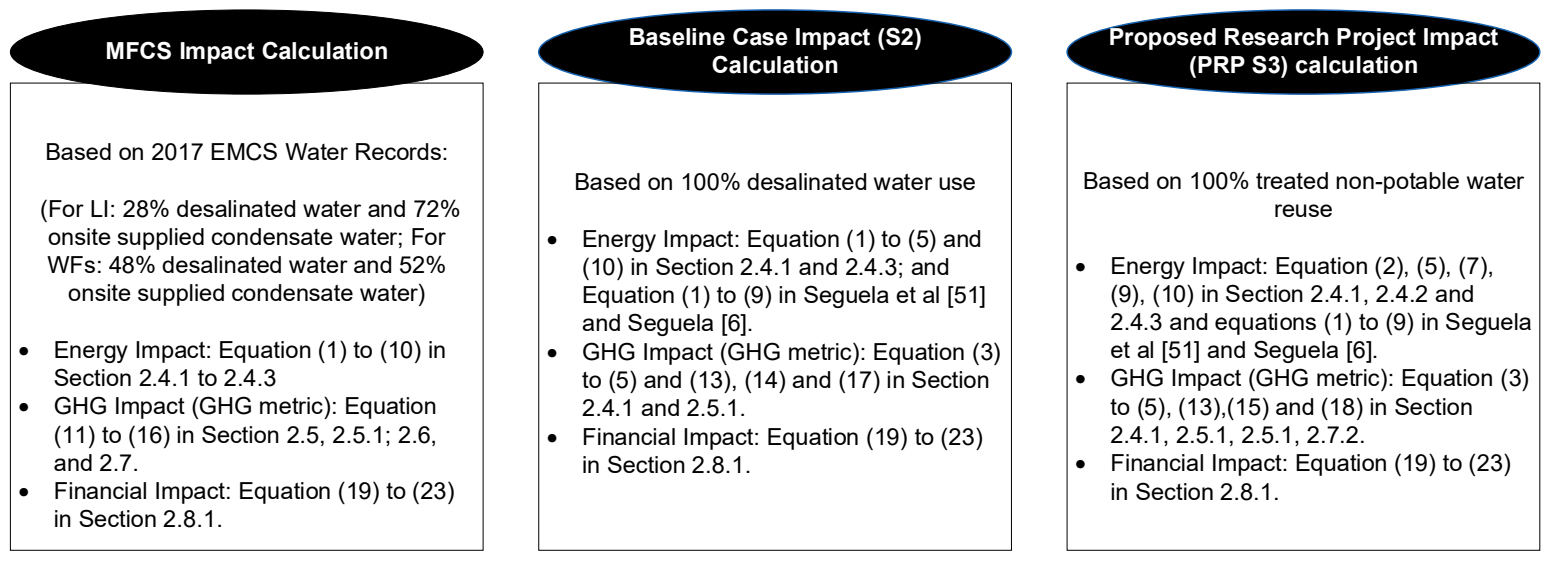

Figure 5. Summary of the energy, environmental and financial impact calculations.

\subsection{Medical facility case study (MFCS) Water System Description}

Referring to Figure A1 and Table A1 in Appendix A, which links to the MFCS non-potable water system configuration diagram in [51] and [6], four pump sets (P1) divert, store, and convey both the condensate water and the desalinated makeup water to the water storage tanks to serve the site. For each of the eight plant rooms serving the WFs, one pump (as part of the P4 pump set) is used to recirculate the water and one or two pumps (as part of the P4 pump set and depending on the ozone plant room configuration) are used to operate the water treatment system and distribute the water to the WFs. An additional one pump set (P5) and two pump sets (P2) are used to distribute the water to the LI as well as an additional pump (P3) to distribute desalinated makeup water to the WFs. The water system uses a total of 26 pumps to operate a combined $3289 \mathrm{~m}^{2}\left(1587 \mathrm{~m}^{3}\right.$ capacity average per month) of decorative WFs and to irrigate $33,257 \mathrm{~m}^{2}$ of landscape. The energy calculations of the treated non-potable water system will be based on the 2017 Energy Monitoring and Control System (EMCS) records (WF and LI water consumption). The peak power demand, the daily energy use, and the seasonal energy demand calculation method for the site has been discussed in [51] as Equations (6)-(9), respectively. All physical and operational characteristics of the outdoor water system were updated and are detailed in Table A1 in Appendix A.

The main electrical consumption accounted for in the MFCS energy calculations are the pumps and the water treatment systems' power consumption. More than $85 \%$ of the total energy used for water systems is drawn by the energy for pumping water [54] and its associated water treatment system [55]. Real energy use for a given water system can vary widely, according to its source configuration [54], however, the largest energy use is by far pumping (ibid.).

The LI system operates 13 hours (h) per day according to the landscape contractor irrigation schedules (5 a.m.-12 p.m.; 6 p.m.-12 a.m.). The WF system's operating hours are based on the EMCS 
pump trends, which showed that pump set (P3) runs for nine minutes (mins) and $75 \mathrm{~s}$ (s) every $20 \mathrm{~min}$, which is $10.67 \mathrm{~h}$ per day $(8.89 \mathrm{~min} \times 3$ times $(20 \mathrm{~min} \times 3=1 \mathrm{~h}) \times 24 \mathrm{~h} / 60(60 \mathrm{~min}$ in one hour). The water demand for the landscape irrigation and the water features were calculated by using Equations (1)-(4) in [51].

\subsection{MFCS Energy and GHG Impact Boundaries}

First, to set operational boundaries and inventory the MFCS activities with respect to direct and indirect emissions (Scope 1, Scope 2, and Scope 3, see Figure 6 for emission targets), the General Reporting Protocol (GRP) [42] was used, which follows both the GHG Protocol Corporate standard [50,56], and the International Standard Organization $14064[57,58]$. Figure 6 provides an overview of the relationship between the three scopes and the activities that generate direct and indirect emissions along the value chain of the MFCS [42].

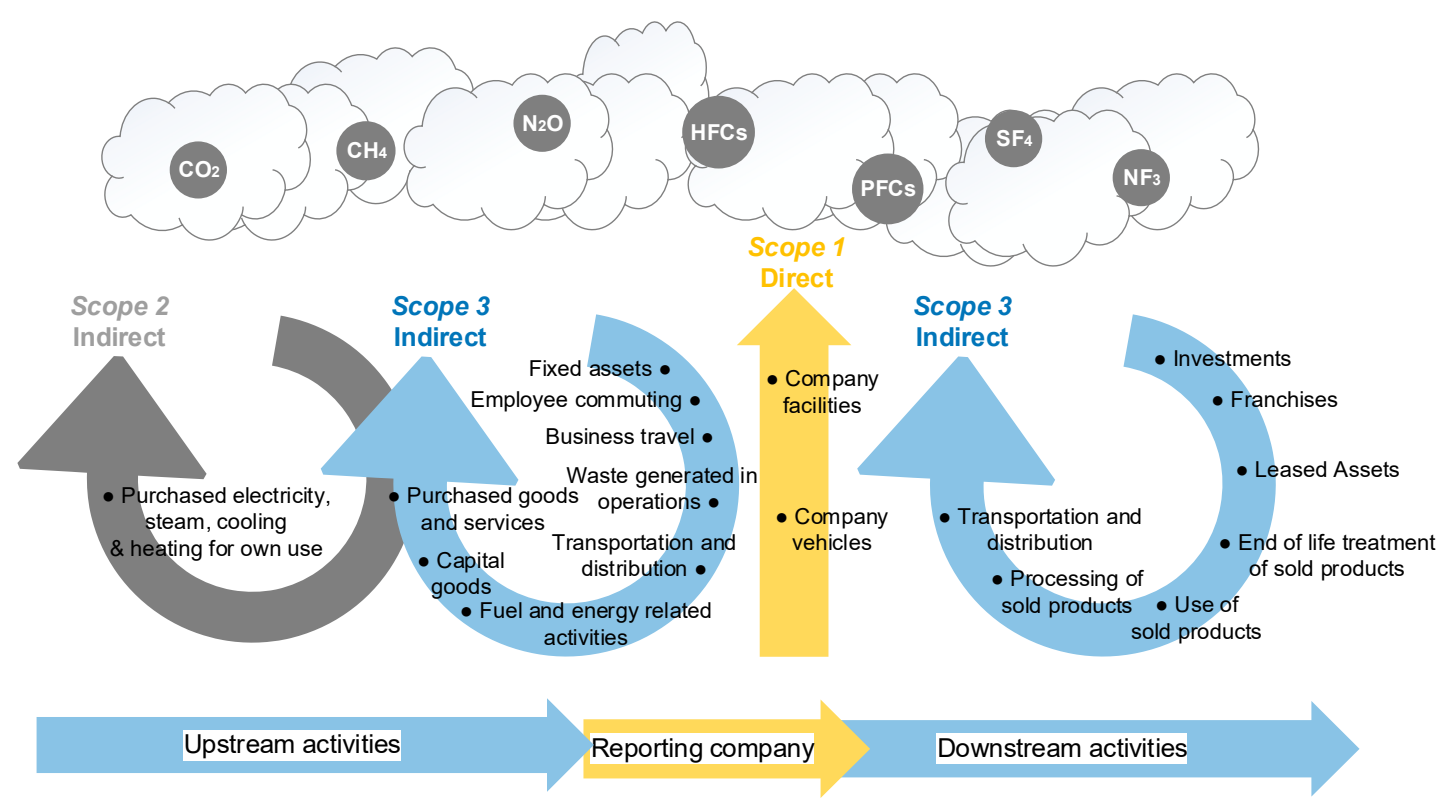

Figure 6. Overview of the GHG protocol scopes and emissions across the value chain [50].

The MFCS indirect emissions expressed in tons of carbon dioxide equivalent $\left(\mathrm{tCO}_{2 \mathrm{e}}\right)$ are accounted in scope two with respect to purchased electricity occurring from upstream activities such as the electrical consumption by onsite pumps and water treatment systems [42,57-59]. Scope 1 is excluded because there are no onsite fossil fuels used for the operation of the MFCS water system. In addition, Scope 3 includes the other non-scope two indirect anthropogenic activities [50]. The GRP [42] does not include the calculation methodologies for Scope 3 emissions, and instead refers to the World Resource Institute (WRI) World Business Council for Sustainable Development (WBCSD) GHG Protocol Corporate standard [50]. However, onsite non-potable water supply and water recycling are not clearly defined in the latter protocol. Thus, considering the above findings, in relation to Section 1.4 including Table 3, a methodology is proposed, which first includes the energy needed by the onsite MFCS non-potable water system to power each step of the water need for outdoor use, adapted from The Climate Registry (TCR) [35]. Second, it includes the end-use of non-potable water and thus the onsite recycled water treatment and distribution needed. Third, the energy use against water consumption is addressed including the consideration of volume reducing factors such as the LI soil enhancement intervention outcome [6] and the WFs' water demand calculation [51]. 


\subsection{MFCS Energy Impact Calculation Method}

The energy demand per day ( $\mathrm{kWh}$ ) for the WFs is the results of Equation (5) in [51], the energy demand (kWh) per day for the LI is the result of Equations (6)-(9) (ibid.). The power (kW) and energy $(\mathrm{kWh})$ demand for LI was developed from Equations (6)-(9) as adapted from Kay and Hatcho [60] in Seguela et al. [51], which were specifically developed for crop irrigation. In addition, the power $(\mathrm{kW})$ and energy $(\mathrm{kWh})$ demand for the WFs were developed from the swimming pool calculation methods [61,62] as per Equation (5) in Seguela et al. [51], with the addition of the pumps' frequency of use. It is estimated that the transfer pumps are used $30 \%$ of the time, and the backwash pumps $10 \%$ of the time.

These calculation methods are like the basic theoretical pump power and pump energy intensity calculation methods of Conway and Rothausen [63], Cheng [64], and Chiu et al. [65]. However, these, like the MFCS calculations, do not include factors for pump power standby-mode and pump power start-up $[66,67]$ due to the lack of information on the number of start-up operations per pump and the power rate for standby mode (see Table 4 for the different calculation methods analyzed by the author). According to Vieira et al. [67] and Ward et al. [68], 60\% to 69\% more energy is used when considering pump standby-mode and pump power start-up in the equation. However, these authors did not consider the shutdown mode for system maintenance, which may also influence the results. Thus, according to the Table 4 literature review [51], the proposed MFCS calculation is a simple method.

Table 4. MFCS energy in water calculation methods.

\begin{tabular}{|c|c|c|}
\hline Literature Review & Method for Calculating Pump Energy Intensity & Water End-Use \\
\hline $\begin{array}{ll}\text { 口 } & {[67]} \\
\text { - } & {[66]}\end{array}$ & $\begin{array}{l}\text { - Pump Input Power }(\mathrm{kW}) \\
\text { - Pump Flow rate in cubic meter per hour }\left(\mathrm{m}^{3} / \mathrm{h}\right) \\
\text { - Pump Start-up }(\mathrm{kWh} / \mathrm{start} \text {-up) } \\
\text { - Number of start-up operations (start-up/day) } \\
\text { - Power rate of standby mode }(\mathrm{kW}) \\
\text { - Standby mode (hours/day) } \\
\text { - } \text { Rainwater consumption }\left(\mathrm{m}^{3}\right)\end{array}$ & $\begin{array}{l}\text { Rainwater reuse for } \\
\text { toilet flushing and } \\
\text { laundry supply in } \\
\text { single-story } \\
\text { detached house }\end{array}$ \\
\hline - $[68]$ & $\begin{array}{l}\text { - Volume pumped during constant flow operation }\left(\mathrm{m}^{3}\right) \\
\text { - Volume pumped during start-up }\left(\mathrm{m}^{3}\right) \\
\text { - Start-up energy factor }(\%) \\
\text { - Motor pump power rating }(\mathrm{kW}) \text { for efficiency calculation } \\
\text { - Motor input power }(\mathrm{kW}) \text { for efficiency calculation } \\
\text { - Pump capacity }\left(\mathrm{m}^{3} / \mathrm{h}\right)\end{array}$ & $\begin{array}{l}\text { Rainwater reuse for } \\
\text { toilet flushing in } \\
\text { office building }\end{array}$ \\
\hline $\begin{array}{ll}\text { 口 } & {[65]} \\
\text { - } & {[64]}\end{array}$ & $\begin{array}{l}\text { - Liquid density in kilogram per cubic meter }\left(\mathrm{kg} / \mathrm{m}^{3}\right) \\
\text { - Gravitation acceleration in meter per second } \\
\text { squared }\left(\mathrm{m} / \mathrm{s}^{2}\right) \\
\text { - Total head }(\mathrm{m}) \\
\text { - Flow Rate in cubic meter per second }\left(\mathrm{m}^{3} / \mathrm{s}\right) \\
\text { - } \text { Motor efficiency }(\%) \\
\text { - Pump efficiency }(\%)\end{array}$ & $\begin{array}{l}\text { Rainwater reuse for } \\
\text { single family } \\
\text { one-story house }\end{array}$ \\
\hline $\begin{array}{l}\text { Calculation adapted } \\
\text { from Forrest and } \\
\text { Williams [61] and } \\
\text { Gallion et al. [62] } \\
\text { Equations (1)-(5) in } \\
\text { Seguela et al. [51] }\end{array}$ & $\begin{array}{l}\text { - } \quad \text { Electricity input }(\mathrm{kWh})(\text { Equation }(5)): \\
-\quad \text { Pump power }(\mathrm{kW}) \\
-\quad \text { Use frequency }(\%) \\
-\quad \text { Pumping shut down during maintenance in hours per } \\
\text { day and days per year } \\
\text { - Total water consumption }\left(\mathrm{m}^{3}\right) \text { which considers: } \\
\text { - WFs water precipitation, evaporation, backflush and } \\
\text { refill (Equations }(1)-(4))\end{array}$ & $\begin{array}{l}\text { Water features } \\
\text { (WFs) }\end{array}$ \\
\hline
\end{tabular}


Table 4. Cont.

\begin{tabular}{|c|c|c|}
\hline Literature Review & Method for Calculating Pump Energy Intensity & Water End-Use \\
\hline $\begin{array}{l}\text { Kay and Hatcho [60] } \\
\text { for Equations (6)-(9) in } \\
\text { Seguela et al. [51]; } \\
\text { Conway and } \\
\text { Rothausen [63] for } \\
\text { Equation (7) (ibid.) }\end{array}$ & $\begin{array}{ll}\text { - } & \text { Peak power demand }(\mathrm{kW})(\text { Equation }(6)) \\
\text { - } & \text { Acceleration of gravity }\left(9.81 \mathrm{~m} / \mathrm{s}^{2}\right) \\
\text { - } & \text { Pump discharge }\left(\mathrm{m}^{3} / \mathrm{s}\right) \\
\text { - } & \text { Pressure/head }(\mathrm{m}) \\
\text { - } & \text { Pumping plant efficiency }(\%) \\
\text { - } & \text { Overall seasonal energy demand }(\mathrm{kWh})(\text { Equation }(7)) \\
\text { - } & \text { Volume of water }\left(\mathrm{m}^{3}\right) \\
\text { - } & \text { Pressure/head }(\mathrm{m}) \\
\text { - } & \text { Water density }\left(367=3600(\mathrm{~s} / \mathrm{h}) \div 9.81\left(\mathrm{~m} / \mathrm{s}^{2}\right)\right. \\
\text { - } & \text { Pumping plant efficiency }(\%) \\
\text { - } & \text { Average daily hours }(\mathrm{kWh}):(\text { Equation }(8)) \\
\text { - } & \text { Overall seasonal energy demand }(\mathrm{kWh}) \\
\text { - } & \text { Crop duration }(\text { days }) \\
\text { - } & \text { Pump power }(\mathrm{kW}) \\
\text { - } & \text { Energy demand per day }(\mathrm{kWh}):(\text { Equation }(9)) \\
\text { - } & \text { Peak power demand }(\mathrm{kW}) \\
\text { - } & \text { Maximum daily pumping hours }\end{array}$ & $\begin{array}{l}\text { Landscape } \\
\text { irrigation (LI) }\end{array}$ \\
\hline
\end{tabular}

The energy impact calculation method followed the MFCS GHG operational boundaries (Section 2.3) set by TCR [42] in line with the WRI/WBCSD [50] GHG Protocol Corporate standard and ISO 14064 Standard $[57,58]$ with respect to GHG direct and indirect emissions (Scope 2 and Scope 3).

\subsubsection{Scope Two}

To calculate the electrical consumption ( $\mathrm{kWh} /$ month), Equation (1) was used for the water feature (WF) system and Equation (2) for the landscape irrigation (LI) system.

WF System Energy demand $(\mathrm{kWh} / \mathrm{month})=$ number of days in a month $\times \mathrm{kWh} /$ day energy consumed

LI System Energy demand $(\mathrm{kWh} / \mathrm{month})=$ number of days in a month $\times \mathrm{kWh} /$ day energy consumed

Calculations (1) and (2) are based on Equations (1)-(5) and (6)-(9) results respectively [6,51], which were reviewed by the MFCS building services engineer. The energy intensity $\left(\mathrm{kWh} / \mathrm{m}^{3}\right)$ of the WF system can be calculated using Equations (3) and (4) for the LI system.

$$
\begin{aligned}
\text { WF System Energy intensity }\left(\mathrm{kWh} / \mathrm{m}^{3} / \text { month }\right) & =\frac{\text { Equation }(1) \text { results }}{\text { Total water consumption }\left(\mathrm{m}^{3}\right)} \\
\text { LI System Energy intensity }\left(\mathrm{kWh} / \mathrm{m}^{3} / \text { month }\right) & =\frac{\text { Equation }(2) \text { results }}{\text { Total water consumption }\left(\mathrm{m}^{3}\right)}
\end{aligned}
$$

The total energy demand ( $\mathrm{kWh} / \mathrm{month})$ for the MFCS water system, WF and LI combined, will be the addition of Equations (1) and (2) as per Equation (5).

The MFCS WF and LI water system energy demand in kWh per month will be the results of Equation (5).

MFCS WF and LI Energy demand in kWh/month = Equation (1) results + Equation (2) results,

and the total energy intensity $\left(\mathrm{kWh} / \mathrm{m}^{3}\right)$ of the MFCS water system (WF and LI combined) will be calculated using Equation (6).

$$
\text { MFCS Energy Intensity }\left(\mathrm{kWh} / \mathrm{m}^{3} / \mathrm{month}\right)=\frac{\text { Equation }(5) \text { results }}{\text { Total water consumption }\left(\mathrm{m}^{3}\right)}
$$




\subsubsection{Scope Three}

To calculate the energy demand of the desalinated water used at the MFCS for the WFs system and the LI system (kWh/month), Equation (7) will be used based on $15.40 \mathrm{kWh} / \mathrm{m}^{3}$ [20] for the desalinated water extraction and diversion energy intensity.

$$
\text { Energy demand }(\mathrm{kWh} / \text { month })=\left(\mathrm{m}^{3} \text { desalinated water used } / \mathrm{month}\right) \times\left(15.40 \mathrm{kWh} / \mathrm{m}^{3}\right),
$$

The energy demand for the extraction, diversion, and treatment of the non-potable water is set to $0 \mathrm{kWh} /$ month (Scope 3) because the condensate water, the reverse osmosis reject water (RORW), and the fire sprinkler pump test water are generated regardless of recycling. The energy demand for its treatment and distribution is included in the water system electrical consumption (Scope 2).

\subsubsection{Scope Two and Three Combined}

The energy intensity $\left(\mathrm{kWh} / \mathrm{m}^{3}\right)$ for the WF and LI system, using $38 \%$ desalinated water and $62 \%$ non-potable water including the water system electrical consumption will be calculated using Equations (8) and (9), respectively.

$$
\begin{gathered}
\text { WF Energy Intensity }\left(\mathrm{kWh} / \mathrm{m}^{3}\right)=\frac{\text { Equation }(7) \text { results }+ \text { Equation }(1) \text { results }}{\text { Total water consumption }\left(\mathrm{m}^{3}\right)} \\
\text { LI Energy Intensity }\left(\mathrm{kWh} / \mathrm{m}^{3}\right)=\frac{\text { Equation }(7) \text { results }+ \text { Equation }(2) \text { results }}{\text { Total water consumption }\left(\mathrm{m}^{3}\right)}
\end{gathered}
$$

The total energy intensity $\left(\mathrm{kWh} / \mathrm{m}^{3}\right)$ for the combined WF and LI system using $38 \%$ desalinated water and $62 \%$ non-potable water including water system electrical consumption will be calculated using Equation (10).

$$
\text { MFCS Energy Intensity }\left(\mathrm{kWh} / \mathrm{m}^{3}\right)=\frac{\text { Equation }(7) \text { results }+ \text { Equation }(5) \text { results }}{\text { Total water consumption }\left(\mathrm{m}^{3}\right)}
$$

These calculations consider the relationship between the total energy consumed against the total water consumed. The GHG emissions calculation in Scope 2 is based on the results from Equations (1) and (2). The GHG emissions for Scope 3 will be based on $38 \%$ desalinated water and $62 \%$ non-potable consumption in $\mathrm{m}^{3}$ as per the 2017 EMCS water records.

\subsection{MFCS GHG Impact Calculation Method}

The steps of the onsite non-potable water use cycle were developed by the author for each water type proposed for reuse. Each $\mathrm{m}^{3}$ extracted, diverted, conveyed, treated, and distributed has an energy expenditure $\left(\mathrm{kWh} / \mathrm{m}^{3}\right)$ and a GHG effect expenditure $\left(\mathrm{tCO}_{2 \mathrm{e}} / \mathrm{m}^{3}\right)$ [69]. The energy intensity for Scopes 2 and 3 will be converted to GHG using the baseline emission factor from [70]. The results will be a GHG metric for onsite non-potable water use by water type as per Equation (11) [35].

$$
\text { Water Energy GHG intensity }\left(\mathrm{kgCO}_{2 \mathrm{e}}\right)=\frac{\text { Total GHG }\left(\mathrm{kgCO}_{2 \mathrm{e}}\right)}{\text { Total water consumption }\left(\mathrm{m}^{3}\right)} \times 1000
$$

First, calculation-based methodologies [42] will be used to quantify Scope 2 emissions (onsite pumps and treatment systems power consumption used to move and treat both desalinated water and non-potable water sources) based on activity data and the EAD [70] and IEA [31] emission factors, 
which are directly given in $\mathrm{CO}_{2 \mathrm{e}}$ equivalent units. This means that the global warming potential (GWP) is equal to $1 \mathrm{CO}_{2 \mathrm{e}}[57,58,71]$ as Equation (12).

$$
\text { GHG emissions }=\sum_{\text {gas }}\left(\text { emissions }_{\text {gas }} \times G W P_{\text {gas }}\right)
$$

Second, Scope 3 emissions will be calculated based on the Water-Energy GHG Guidance [35] and WRI/WBCSD [50] protocol. Electricity consumption associated with the production of desalinated water falls under Scope 3 because the fuel and energy related activities to produce this water type are not included in Scopes 1 and $2[35,50]$. Whereas, non-potable water supply such as RORW, food waste effluent wastewater, $\mathrm{A} / \mathrm{C}$ condensate water, and fire sprinkler pump test water fall within Scope 3 as energy:water decarbonization, which is currently not defined by the GHG protocol standards $[50,56]$ nor the GRP standards [35,42].

Calculation Process for Scope Two and Scope Three

For Scope 2, the formula for calculating the total GHG emissions of the non-potable water system for electricity is calculated by using Equation (13) $[42,57,58]$, where the GHG emission factor (EF) from electricity generation in the UAE is $0.64337 \mathrm{kgCO}_{2 \mathrm{e}} / \mathrm{kWh}$ [31]. This greenhouse gas emission factor (GHGEF) excludes transmission and distribution losses between the power station and the end-user (ibid.)

$$
\text { Electricity generation }(\mathrm{kWh}) \times \mathrm{GHG}_{\mathrm{EF}}(\mathrm{IEA}, 2016)\left(\mathrm{tCO}_{2 \mathrm{e}} / \mathrm{kWh}\right),
$$

The electricity consumption in $\mathrm{kWh}$ is the power demand of the water system for all scenarios (MFCS, Baseline Case (S2), Proposed Research Project (PRP S3) because power will be needed to distribute the water to the point of consumption regardless of the water type used. The only exception is the ultraviolet (UV) disinfection treatment system which was excluded for scenario two (Baseline Case S2). The $\mathrm{kWh} / \mathrm{month}$ will be the result of Equation (5).

For Scope 3, the GHG emissions for desalinated water is calculated by using Equation (14) [70] where the GHGEF for water consumption in $\mathrm{AD}$ is $0.0151 \mathrm{tCO}_{2 \mathrm{e}} / \mathrm{m}^{3}$ [69]. The GHG water:energy decarbonization is calculated by using Equation (15) [50] with the same GHGEF [70].

$$
\begin{aligned}
& \text { Desalinated Water Consumption }\left(\mathrm{m}^{3}\right) \times \mathrm{GHG}_{\mathrm{EF}}(\mathrm{EAD}, 2012)\left(\mathrm{tCO}_{2 \mathrm{e}} / \mathrm{m}^{3}\right) \text {, } \\
& \text { Non-Potable Water Consumption }\left(\mathrm{m}^{3}\right) \times \mathrm{GHG}_{\mathrm{EF}}(\mathrm{EAD}, 2012)\left(\mathrm{tCO}_{2 \mathrm{e}} / \mathrm{m}^{3}\right) \text {, }
\end{aligned}
$$

\subsection{MFCS Calculation Evaluation against Alternative Scenarios (S2 and PRP S3)}

The MFCS water system uses 32\% makeup desalinated water and $68 \%$ condensate water. To evaluate the impact on energy use and costs and the associated GHG emissions, the latter was compared to a baseline (Scenario 2) and to the propose research project (Scenario 3). The parameters of the MFCS and the alternative scenarios are summarized in Table 5. 
Table 5. MFCS parameters against alternative scenarios (S2 and PRP S3).

\begin{tabular}{|c|c|c|c|}
\hline & MFCS Scenario 1 & $\begin{array}{l}\text { Baseline Case } \\
\text { Scenario } 2(\mathrm{~S} 2)\end{array}$ & $\begin{array}{l}\text { Proposed Research Project } \\
\text { Scenario } 3 \text { (PRP S3) }\end{array}$ \\
\hline $\begin{array}{l}\text { Initial investment (design } \\
\text { and construction) }\end{array}$ & $\begin{array}{l}\text { Water tanks, piping, flow } \\
\text { meters, pumps, EMCS } \\
\text { connection, UV disinfection and } \\
\text { Ozone treatment systems. }\end{array}$ & $\begin{array}{l}\text { Pumps, EMCS connection, } \\
\text { and ozone disinfection } \\
\text { treatment system. }\end{array}$ & $\begin{array}{l}\text { Water tanks, piping, flow } \\
\text { meters, pumps, EMCS } \\
\text { connection, UV disinfection, and } \\
\text { ozone treatment systems. }\end{array}$ \\
\hline $\begin{array}{l}\text { Annual landscape } \\
\text { maintenance }\end{array}$ & - Soil conditioner B. & & - Soil conditioner B. \\
\hline $\begin{array}{l}\text { Annual water system } \\
\text { maintenance }\end{array}$ & $\begin{array}{l}\text { Chlorine; laboratory } \\
\text { analysis; tank disinfection. }\end{array}$ & $\begin{array}{l}\text { - Chlorine; } \\
\text { - Laboratory analysis. }\end{array}$ & $\begin{array}{l}\text { - Chlorine; } \\
\text { - Laboratory analysis; } \\
\text { - Tank disinfection; } \\
\text { - Chemigation. }\end{array}$ \\
\hline $\begin{array}{l}\text { Annual water type } \\
\text { consumption }\end{array}$ & $\begin{array}{l}\text { - Combined desalinated and } \\
\text { non-potable water sources: WFs: } \\
52 \% \text { condensate water; } 48 \% \\
\text { makeup water; } \mathrm{LI}: 72 \% \\
\text { condensate water; } 28 \% \text { makeup } \\
\text { water. }\end{array}$ & $\begin{array}{l}100 \% \text { desalinated water } \\
\text { consumption: } \\
\text { WF water demand is } \\
\text { based on the } 2017 \text { EMCS } \\
\text { records. } \\
\text { LI water demand is } \\
\text { based on ADM [ } 53] \\
\text { standard with no soil } \\
\text { improvement. }\end{array}$ & $\begin{array}{l}100 \% \text { mixed non-potable water } \\
\text { supply (condensate, fire } \\
\text { sprinkler pump test water, RO } \\
\text { reject water): } \\
\text { G WFs demand is based on } \\
\text { Seguela et al.'s [28] water } \\
\text { demand calculation. } \\
\text { LI water demand is based on } \\
\text { demand after soil improvement. }\end{array}$ \\
\hline Additional parameters & $\begin{array}{l}\text { Soil improvement partially } \\
\text { implemented; } 13 \text { hours }(\mathrm{h}) \text { run } \\
\text { time irrigation controller per } \\
\text { day, } 10.67 \mathrm{~h} \text { for the WF system. }\end{array}$ & $\begin{array}{l}\text { - } 13 \mathrm{~h} \text { run time irrigation } \\
\text { controller per day; } \\
\text { - } 10.67 \mathrm{~h} \text { for the } \mathrm{WF} \\
\text { system. }\end{array}$ & $\begin{array}{l}\text { - Soil improvement } 100 \% \\
\text { implemented; } \\
\text { - } 8 \mathrm{~h} \text { run time irrigation } \\
\text { controller per day; } \\
\text { a } 6 \mathrm{~h} \text { for the WF system; } \\
\text { - Leaks detected and repaired; } \\
\text { - Hydraulic review } \\
\text { recommendations } 100 \% \\
\text { implemented; } \\
\text { a } 365 \text { days/year operations for } \\
\text { the RORW pump and } 1 \text { day } \\
\text { operation per year for the fire } \\
\text { sprinkler pump test water. }\end{array}$ \\
\hline Annual energy tariff & & & $\begin{array}{l}\text { AED 0.21/kWh, equivalent to } \\
\text { USD 0.057/kWh [22] }\end{array}$ \\
\hline Annual water tariff & \multicolumn{2}{|c|}{ The calculation will ignore the water and energy subsidies } & $\begin{array}{l}\text { AED } 8.23 / \mathrm{m}^{3} \text { equivalent to USD } \\
2.24 / \mathrm{m}^{3}[22]\end{array}$ \\
\hline \multicolumn{3}{|c|}{ Life span of the project (assumption) } & 20 years \\
\hline \multicolumn{3}{|c|}{ UAE interest rate in January 2018 (Central Bank of the United Arab Emirates [72]. } & $4.8 \%$ \\
\hline \multicolumn{3}{|c|}{ UAE inflation rate in January 2018 [73]. } & $2.25 \%$ \\
\hline
\end{tabular}

The three scenarios (MFCS, S2, PRP S3) include the secondary treatment system energy demand to regulate the $\mathrm{pH}$, and to prevent corrosion of the system if the desalinated or non-potable water source is acidic [74]. The three case scenarios, summarized in Table 5, provides the energy intensity and associated GHG impact for each segment of the water cycle onsite during operations as illustrated in Figure A1 in Appendix A. Hence, the calculation will include the energy intensity for extracting and diverting, storing, conveying, treating, and distributing water onsite in line with Scope 2 of the GRP [42] and ISO 14064 part two [58]. Plus, it will include the energy intensity for producing both desalinated and non-potable water in line with Scope 3 of the GRP [42], the Greenhouse Gas Protocol [50], and ISO $14064[57,58]$, expressed in $\mathrm{kWh} / \mathrm{m}^{3}$. The GHG emissions will be calculated on this basis.

\subsection{MFCS 2017 EMCS Records}

The total GHG emissions and decarbonization can be calculated by deducting the Equation (15) results from the results from Equations (13) and (14), as per Equation (16). Equation (14) will account for 
the portion of desalinated makeup water consumed and Equation (15) for the portion of non-potable water consumed. The GHG emissions account for both Scopes 2 and 3.

Total GHG emissions or decarbonization =

[Equation (13) results + Equation (14) results] - Equation (15) results

\subsubsection{Baseline Case Scenario Two (S2)}

The total GHG emissions and decarbonization can be calculated by adding the Equation (13) results to the Equation (14) results as per Equation (17).

$$
\text { Total GHG emissions = Equation (13) results + Equation (14) results }
$$

\subsubsection{Proposed Research Project Scenario Three (PRP S3)}

The total GHG emissions and decarbonization can be calculated by deducting the Equation (13) results from the Equation (15) results as per Equation (18).

Total GHG decarbonization = Equation (13) results - Equation (15) results

Table A2 in Appendix A provides a summary of the water energy GHG intensity calculation methodology for the MFCS. It is assumed that the $15.40 \mathrm{kWh} / \mathrm{m}^{3}$ [20] energy intensity rate for desalinating water and its associated emission factor [70] includes production, transmission, distribution and supply, and excludes the $8 \%$ water real loss provided by the Regulation Supervision Bureau (RSB) [75].

\subsection{MFCS Financial Impact Calculation Method}

\section{Discounted Cash Flow Method Analysis}

The primary criterion for assessing the effectiveness of energy conservation investments is the minimization of life cycle costs [76]. For a project to be considered as life-cycle cost (LCC) effective, it must have a net-present value (NPV) greater than or equal to zero, or an internal rate of return greater than the estimated discount rate [77]. Equally, the decision rule can be the choice of a scenario with the lowest LCC as per DeYong [78] in Capehart et al. [76]. For energy related projects, an LCC study should include the consideration of costs for at least the design, initial construction, energy and utilities, operations and maintenance, repairs, replacement, and salvage [79]. As the MFCS and the two alternative case scenarios do not consider, for instance, the energy for chemical production, they do not qualify as a fully completed LCC analysis. The MFCS and the two alternative case scenarios include the total cost of purchasing and operating the potable and non-potable water system over their assumed lifespan, excluding repairs, replacement and salvage and thus have been analyzed with a discounted cash flow method analysis.

The simple payback period (SPP) determines the number of years required to recover the initial investment through the project (MFCS, S2, and PRP3) return and is calculated following Equation (19) [79].

$$
\mathrm{SPP}=(\text { Initial cost }) /(\text { Annual savings })
$$

The SPP methodology does not consider the time value of money, Capehart et al. [76] recommend using a combination of methods that include values such as the discounted cash flow method. The net present value or present worth (PW) can be used as a combination method with SPP [78]. NPV converts future cash flows by using a given discount rate and is used to convert future saving cash flows of the MFCS non-potable water system back to the present, which is then compared to the cost of the two alternative scenarios. If the NPV is positive, the investment is acceptable [80]. The NPV of the MFCS and the two alternative scenarios (S2 and PRP S3) can be calculated using a minimum attractive 
rate of return (MARR) or discount rate estimated by the Equation (20) mathematical relationship below [78], based on the UAE real interest and inflation rates where $i$ is the market interest rate; $f$ is the inflation rate; and $\mathrm{j}$ is the real interest rate.

$$
i=f+j+f \times j
$$

Equation (21) (ibid., p. 141) can be used to find the present worth (P) of the MFCS against Scenarios 2 and 3 where $i$ is the interest percentage and $A$ is the initial investment for $n$ years or life span of the project (Equation (21).

$$
P=A(1+i \wedge n)
$$

The reciprocal relationship between $\mathrm{P}$ and $\mathrm{A}$ is symbolized by the factor $(\mathrm{P} / \mathrm{A}(\mathrm{i}, \mathrm{n}))$ and is called the uniform series, capital recovery factor [79]. The present worth factor $(1+i \hat{n})$ is extracted from the uniform series tables of $(\mathrm{P} \mid \mathrm{A}, \mathrm{i}, \mathrm{n})$ in Capehart et al. [76] to estimate the annual savings of the MFCS against the two alternative scenarios over 20 years.

The results are then generated and compared by using Equations (22) and (23) for the MFCS and the two-alternative scenarios.

$$
\begin{gathered}
\mathrm{NPV}=\text { initial cost }-\mathrm{PW} \text { of water savings }\left[\mathrm{P}=\mathrm{A}\left(1+\mathrm{i}^{\wedge} \mathrm{n}\right)\right]+\mathrm{PW} \text { of annual costs }\left[\mathrm{P}=\mathrm{A}\left(1+\mathrm{i}^{\wedge} \mathrm{n}\right)\right] \\
\text { Benefit/cost ratio }(\mathrm{BC})=\text { Equivalents/Equivalents cost }
\end{gathered}
$$

where the benefits are the annual savings and the equivalent costs are the maintenance in addition to the energy and water costs. When the $\mathrm{BC}$ is greater than 1 , the project is deemed economically attractive [78]. The total cost will include the estimated costs of installing and operating a system (including energy and water costs, and maintenance) as per the MFCS operation mode (use of non-potable water and makeup potable water) against a potable water system (S2) and a non-potable water system (PRP S3).

\section{Anticipated Results}

Discussing the detailed results is not within the scope of this paper. However, a summary is given of the anticipated results at the MFCS if a full implementation of the methods discussed above is undertaken: water system energy impact, the environmental impact, and the financial impact calculation.

\subsection{MFCS Water System Energy Impact}

The MFCS results establish the energy consumption calculation method for a water system using $38 \%$ desalinated makeup water and $62 \%$ treated non-potable water (LI and WF water consumption combined) as per the EMCS water consumption records (February 2017-January 2018). Seguela et al. [51] established the energy consumption based on a $4200 \mathrm{~m}^{3}$ average per month for the LI (2016 records). The water consumption was revised according to the EMCS records for 2017 where an $8783 \mathrm{~m}^{3} / \mathrm{month}$ average of condensate water and $4599 \mathrm{~m}^{3} /$ month average of desalinated makeup water were used for the WFs and the LI. In addition, Seguela et al. [51] calculated the energy consumption for the LI based on one-hour operation per day. The landscape contractor updated the irrigation controller schedules in September 2017, which brings the run time for the irrigation to $13 \mathrm{~h}$ per day. Additionally, both the WF and the LI calculations excluded the water treatment systems' energy consumption. Thus, the energy calculation results have been revised since Seguela et al.'s [51] publication. The Forrest and Williams [61] calculation method for swimming pools, adapted here for the WFs, is based on the open and closed season (days and hours of operation), the power (kW) used per pump, and the water consumed. In addition to these, Seguela et al. [51] added the frequency of use in percentage per pump to align to the MFCS' mode of operation. The WF pump power and flow rate ( $\mathrm{kW}$ and $\mathrm{m}^{3} / \mathrm{h}$ ) to satisfy the maximum anticipated operating conditions are variables that have been decided at the design stage by the mechanical engineer [54]. For the LI, the Kay and Hatcho [60] calculation 
method considers the pumps' peak power demand (based on the existing pump size), the pumps' frequency of use, in addition to the quantity of water used. Thus, it is also possible to analyze and compare the MFCS results for LI with different variables such as various irrigation controller times and the various quantities of water used to observe changes in energy use. Seguela et al. [51] revised calculation considers the portion of water type consumed by the site for the 12-month period (February 2017 to January 2018).

\subsection{MFCS Environmental Impact calculation}

The LI and the WF system uses 38\% desalination makeup water and $62 \%$ condensate water as recorded by the EMCS. The proposed MFCS calculation method will provide the environmental impact this mixed use of water will have on the environment in terms of GHG emission or decarbonization in $\mathrm{kgCO}_{2 \mathrm{e}} / \mathrm{m}^{3}$.

The environmental impact calculation includes decarbonization (Scope 3) from the condensate water used by the WF and the LI system less the GHG emissions emitted using makeup desalinated water; and less the GHG emissions emitted by the MFCS electrical system (Scope 2) of the treated nonpotable water.

\subsection{MFCS Financial Impact Calculation}

As discussed in Section 2.8, the NPV converts the value of the future cash flow of the MFCS and the two alternative case scenarios (S2 and PRP S3) by using the estimated discount rate (16\%) up to the value in 2018 [77]. The NPV converts the worth of the future cash flows for each scenario by using the estimated discount rate (16\%) to the value in 2020, as the rate was determined in 2018.

This analysis does not take into consideration all cost variables such as the water treatment systems' spare parts or maintenance replacement (for example UV disinfection system cartridge filters) and MEP equipment salvage. However, the analysis provides an indication of the cost benefits of a system using a combination of non-potable water and desalinated water over 20 years (i.e., 2018-2038). Comparing the MFCS to a baseline case (Scenario 2, S2) and the proposed research project (Scenario 3, PRP S3) will help to evaluate the values of these three case scenarios.

\section{Discussion}

The contributions to knowledge and professional practice for building owners, engineers, facility managers, and other practitioners engaged in maintaining and managing building estates that use LI and WFs are discussed below. In addition, the limitations to the research are also discussed.

\subsection{Contributions from the GHG Metric Methodology for Onsite Non-Potable Water Systems}

Electricity consumption associated with water and wastewater operations are a major contributor to GHG emissions [35-39]. In addition, and this remains to the authors' knowledge in 2020, the energy intensity of non-potable water supply sources (other than desalination water) and decentralized water systems "are unknown and is a knowledge gap that requires further research" [36]. Moreover, the design of methodologies to account for these GHG emissions have not been transparently available [35]. Thus, another contribution to knowledge and professional practice is the design and development of a GHG metric to determine the environmental impact of reusing non-clinical and non-potable water sources onsite, compared with the use of potable desalinated water for LI and WF use. The authors developed a calculation methodology to determine the energy intensity of onsite generated non-potable water sources, compared with desalinated potable water for outdoor WFs and LI use, by applying this method to:

- First, a mixture of condensate water and desalinated water (MFCS scenario);

- Second, desalinated water (Baseline Scenario 2, S2); 
- Third, a case for additional non-potable water sources used as makeup water to the main water source (condensate water) such as fire sprinkler pump test water and RORW (Scenario 3, PRP S3).

This methodology was developed as a result of the results of a GHG metric $\left(\mathrm{kgCO}_{2 \mathrm{e}} / \mathrm{m}^{3}\right)$, which specifically includes the energy impact from outdoor water demand, water type supply, and onsite distribution systems to help evaluate water conservation strategies. The metric determines GHG emissions (-) or sinks (+) in water for outdoor use and is presented in Table A2 in Appendix A, where it can be used to evaluate the three case scenarios (MFCS, S2, and PRP S3). The use of 100\% non-potable water sources combined with water demand control, and an efficient onsite distribution system can be a powerful asset for decarbonization.

\subsection{Contributions and Target Audience}

The original and significant contribution to change in professional practice and knowledge will be most useful to building and estate owners, facility managers, and landscape contractors, who are responsible for saving water for outdoor use, increasing non-potable water use against potable water, and minimizing costs and GHG emissions during operations. In addition, the contributions could form part of the design of a decentralized non-potable water system intended for existing and new building landscapes and WFs.

\subsection{Research Limitations}

\subsubsection{Estimation of Cost and GHG Calculations}

The reporting of GHG emissions implies the use of appropriate methodologies and the use of country-specific emission factors that are publicly available, and that have been published following a rigorous peer-reviewed process [42]. In the UAE, the accuracy of the GHG emissions inventory is uncertain for three reasons: (1) data access is a constraint; (2) the use of generic emission factors is potentially unsuitable; and (3) the processes associated with emissions is incompletely understood [16]. For instance, the available data format, which suits government planning purposes, does not necessarily address all information required by the IPCC [59] methodology [16]. Due to these limitations, future research could be undertaken to provide further evidence and thus meet the IPCC methodology.

\subsubsection{Energy Calculations}

The pumps' energy intensity calculated for the WFs and the LI water diversion, storage, conveyance, treatment, and distribution did not take into consideration the pumps standby mode and start-up $[66,67]$. This is because the energy consumption for pump start-up and standby mode, and the number of start-up operations per day were not known and would have required additional funding (not available to the authors) to contract the building engineer to undertake this work. In addition, it is not known if the energy intensity of the desalinated water production $\left(15.40 \mathrm{kWh} / \mathrm{m}^{3}\right)$ includes both of these factors.

\subsection{Recommendations}

The DEng change project has demonstrated that a water supply, specifically coming from a non-potable water source, can be used as a decarbonization strategy in Abu Dhabi, which could also be transferred to countries located in arid climates that have limited access to natural resources and depend on desalinated water.

The following recommendations from the authors are therefore to encourage the local authority to develop a sustainable water conservation and reuse (SWC) strategy, forming the basis for a water protocol including an assessment methodology to measure the impact of decentralized buildings' non potable water systems GHG emissions and their financial viability with the design and development of a water:energy GHG metric in $\mathrm{kgCO}_{2 \mathrm{e}} / \mathrm{m}^{3}$, as summarized in Figure 7. This proposed calculation method, using equations $[35,51,60-62,69,76-79]$ from the literature, fills the knowledge gap with regard 
to assigning values of building water streams (Figure A1 in Appendix A) while accounting for the energy intensity of non-potable water supply sources for a decentralized water system.

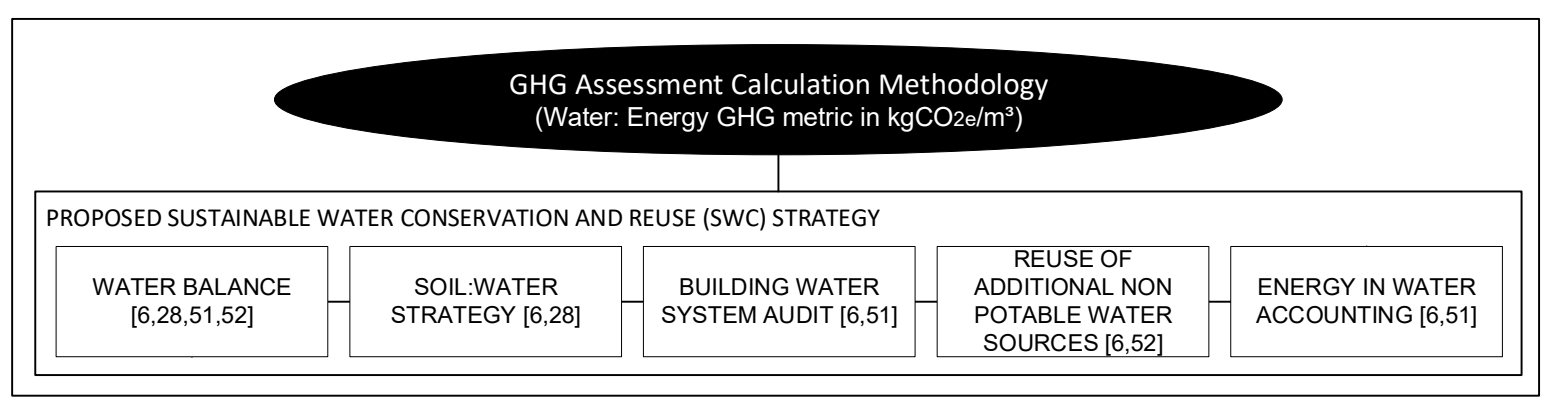

Figure 7. Summary of the Water Conservation Protocol for a decentralized system.

The findings for collecting water and energy data to produce the calculations can be summarized as follows:

- A water balance to allow for the comparison of an onsite system as opposed to the use of municipal desalinated potable water. The water consumption records are to be collected and analyzed daily via sub flow meters connected to the EMCS. Additionally, these water data are to be compared with water bills to cross check the accuracy of the collected data and establish cost savings. This action research benefit is to help provide an account for the effect of non-potable water on landscape for water efficiency and water deficit offset feasibility analysis [6,28,51,52].

- Establishing an irrigation water budget to create a baseline for LI irrigation demand against a suitable irrigation rate and irrigation controller schedule [6,28].

- Conducting water and soil quality tests and building water system audits for implementation of a soil water strategy that could reduce substantial water consumption $[6,28]$.

- In addition to air conditioning condensate water, account for additional non potable water supply suitable for reuse as makeup water by conducting a building water audit $[6,51,52]$.

- Accounting for the building operational boundaries for equipment electrical consumption serving the water systems $[6,51]$.

These recommendations apply to the design and construction industry as well as to the building operations and maintenance industry who are willing to improve their outdoor water conservation programs to save on cost and minimize environmental impact.

\section{Conclusions}

The case study presented is a medical facility in AD and the existing treated non-potable water system for LI and WF use has been discussed. The MFCS, which uses $62 \%$ condensate water and $38 \%$ desalinated makeup water on average for both the LI and the WF system, was compared to a baseline and to the proposed research project.

The findings have led to a proposed sustainable water strategy, which could be legislated and mandated by the competent authority for regional medical facilities as part of a water conservation protocol with a water:energy GHG Metric $\left(\mathrm{kgCO}_{2 \mathrm{e}} / \mathrm{m}^{3}\right)$, to assess the water systems of building estates that serve outdoor LI and WFs.

The proposed calculation method will contribute to developing the energy and financial impact from an outdoor water demand, the supply of the water type, and onsite distribution systems in terms of GHG emissions or sinks in water for outdoor use, and provide an indication of the cost benefits of a system using a combination of non-potable water and potable desalinated water.

The next steps are to publish the anticipated results of the three case scenarios, which are being developed for another paper. 
Author Contributions: Conceptualization, G.S.; Methodology, G.S.; Software, G.S.; Formal analysis, G.S.; Investigation, G.S.; Resources, G.S.; Writing—original draft preparation, G.S.; Writing-reviewing and editing in all sections; Supervision J.R.L.; and G.K. All authors have read and agreed to the published version of the manuscript.

Funding: This research received no external funding.

Acknowledgments: Our very special gratitude goes to the Medical Facility (MF) for their support, with a special mention to the Chief Academic Officer and Chief Cardiovascular Medicine in the Heart and Vascular Institute at the MF; the Senior Director hospital operations at the MF; and members of the building owner's team. The main author is also grateful to the MF staff and contractors: the building services specialist, the Mechanical Electrical Plumbing management team, and the landscape contractor's management team.

Conflicts of Interest: The authors declare no conflict of interest.

\section{Abbreviations}

$\begin{array}{ll}\text { AC CW } & \text { Air Conditioning condensate water } \\ \text { AD } & \text { Abu Dhabi } \\ \text { ADM } & \text { Abu Dhabi Municipality } \\ \text { AED } & \text { Emirati Dirham } \\ \text { D.Eng } & \text { Doctorate in Engineering } \\ \text { EAD } & \text { Abu Dhabi- Environment Agency } \\ \text { EMCS } & \text { Energy Monitoring and Control System } \\ \text { GHG } & \text { Greenhouse gas } \\ \text { IPCC } & \text { Intergovernmental Panel on Climate Change } \\ \text { LI } & \text { Landscape Irrigation } \\ \text { MED } & \text { Multi Effect Distillers } \\ \text { MFCS } & \text { Medical Facility Case Study } \\ \text { MSF } & \text { Multistage flash } \\ \text { RO } & \text { Reverse Osmosis } \\ \text { S2 } & \text { Baseline case scenario 2 } \\ \text { PRP S3 } & \text { Proposed research project Scenario 3 } \\ \text { TCR } & \text { The Climate Registry } \\ \text { TSE } & \text { Treated Sewage Effluent } \\ \text { UAE } & \text { United Arab Emirates } \\ \text { WF } & \text { Water feature } \\ \text { WFs } & \text { Water features }\end{array}$




\section{Appendix A. Methodology}

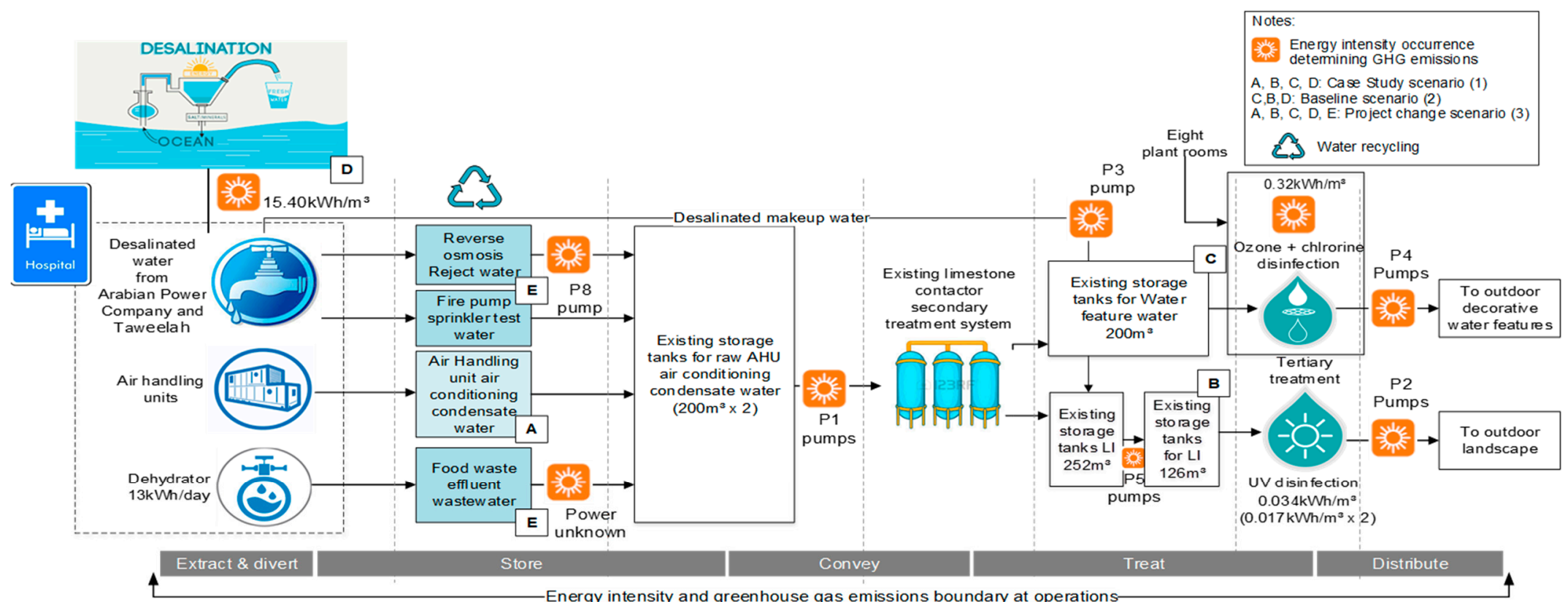

Notes on water treatment systems:

1. $\quad 0.32 \mathrm{kWh} / \mathrm{m}^{3}$ accounts for ozone generation, drying of the feed gas cooling of the ozone generator, injection units and instrumentation control [55]

2. $\quad 0.017 \mathrm{kWh} / \mathrm{m}^{3}$ accounts for the production of radiation and heat $[55,81]$.

It is assumed the same quantity of energy will be used by the cartridge filters unit.

Figure A1. MFCS, S2, and PRP S3 calculation boundaries. Figure A1 is linked to Table A1 and the MFCS non-potable water system configuration diagram in Seguela [6] and Seguela et al. [51]. 
Table A1. Updated MFCS main operation input summary [6].

\begin{tabular}{|c|c|c|c|c|c|}
\hline \multicolumn{4}{|c|}{ Input Summary } & \multicolumn{2}{|c|}{ Mean Average } \\
\hline \multicolumn{6}{|c|}{ 1. Physical characteristics } \\
\hline \multicolumn{4}{|c|}{ Outdoor elements } & WFs & LI \\
\hline \multicolumn{4}{|c|}{ Area $\left(\mathrm{m}^{2}\right)$} & 3289 & 36,310 \\
\hline \multicolumn{6}{|c|}{ 2. Operational parameters } \\
\hline Pumps (h/day) & & & & 11.7 & 13 \\
\hline $\begin{array}{l}\text { Backwash period (No per } \\
\text { month)_assumption }\end{array}$ & & & & 4 & $\mathrm{n} / \mathrm{a}$ \\
\hline $\begin{array}{l}\text { Backwash duration } \\
\text { (mins)—assumption }\end{array}$ & & & & 15 & $\mathrm{n} / \mathrm{a}$ \\
\hline Refill period (years) & & & & 0.5 & $\mathrm{n} / \mathrm{a}$ \\
\hline \multicolumn{6}{|c|}{ 3. Environmental Conditions } \\
\hline Season (length) in days & & & & $\begin{array}{l}351 \text { ( } 14 \text { days for } \\
\text { maintenance) }\end{array}$ & $\begin{array}{c}365 \text { (2017); } 366 \\
(2016)\end{array}$ \\
\hline $\begin{array}{l}\text { Rainfall (mm) average per } \\
\text { month) }\end{array}$ & & & & \multicolumn{2}{|c|}{$\begin{array}{l}3.80 \mathrm{~mm} \text { (November to April); } 0 \mathrm{~mm} \\
\text { (May to October); (SCAD, 2017) }\end{array}$} \\
\hline $\begin{array}{l}\text { Evaporation (mm) } \\
\text { average per month }\end{array}$ & & & & \multicolumn{2}{|c|}{$\begin{array}{l}215 \mathrm{~mm} \text { (November to April); } 0 \mathrm{~mm} \\
\text { (December to March); (SCAD, 2017) }\end{array}$} \\
\hline \multicolumn{6}{|c|}{ 4. Existing Water System Components } \\
\hline Pump Description & $\begin{array}{l}\text { Pump Power } \\
(\mathrm{kW})\end{array}$ & $\begin{array}{l}\text { Pump Flow } \\
\qquad\left(\mathrm{m}^{3} / \mathrm{h}\right)\end{array}$ & $\begin{array}{l}\text { Pump Usage } \\
\text { per day }(\%)\end{array}$ & WFs & LI \\
\hline & & & & \multicolumn{2}{|c|}{ Number of pumps } \\
\hline (P1) Pumps Set A & 4 & 17 & 30 & \multicolumn{2}{|c|}{1} \\
\hline (P1) Pumps Set B & 11 & 64 & 10 & \multicolumn{2}{|c|}{1} \\
\hline (P1) Pumps Set C & 4 & 17 & 30 & \multicolumn{2}{|c|}{1} \\
\hline (P1) Pumps Set D & 11 & 64 & 10 & \multicolumn{2}{|c|}{1} \\
\hline (P2) Pumps Set power & 18.5 & 64 & 100 & - & 1 \\
\hline (P2) Pumps Set power & Not known & 10 & 100 & - & 1 \\
\hline (P3) WE Pump Set & 7.5 & 45.5 & 100 & 1 & - \\
\hline (P5) Pumps Set power & 11 & 63.3 & 100 & - & - \\
\hline (P4) Ozone Filter Pump & 5.5 & Not known & 100 & 5 & - \\
\hline (P4) Ozone Display Pump & 30 & Not known & 100 & 4 & - \\
\hline (P4) Ozone Filter Pump & 2.2 & Not known & 100 & 2 & - \\
\hline (P4) Ozone display Pump & 37.5 & Not known & 100 & 1 & - \\
\hline (P4) Ozone display Pump & 3.7 & Not known & 100 & 1 & - \\
\hline (P4) Ozone display Pump & 11.2 & Not known & 100 & 1 & - \\
\hline Ozone Disinfection & & $.31 \mathrm{kWh} / \mathrm{m}^{3}$ [55] & & $40.15 \mathrm{kWh} /$ day & - \\
\hline
\end{tabular}


Table A2. MFCS non-potable water use cycle segments adapted from The Climate Registry [42].

\begin{tabular}{|c|c|c|c|c|c|c|c|c|c|c|c|}
\hline \multirow{2}{*}{ Water Product } & \multicolumn{5}{|c|}{ Five Major Water Use Cycle Segments to Model GHG Emissions at Operations } & \multirow{2}{*}{$\begin{array}{l}\text { GHG Protocol } \\
\text { Scope } \\
{[35,42,57,58]}\end{array}$} & \multirow{2}{*}{$\begin{array}{l}\text { Total GHG } \\
\text { Emissions/Sinks } \\
\text { in } \mathrm{CO}_{2 e}\end{array}$} & \multirow{2}{*}{$\begin{array}{l}\text { Energy Demand } \\
\text { in kWh Per Year }\end{array}$} & \multirow{2}{*}{$\begin{array}{l}\text { Energy } \\
\text { Intensity in } \\
\mathrm{kWh} / \mathrm{m}^{3}\end{array}$} & \multirow{2}{*}{$\begin{array}{l}\text { Volume of Water } \\
\text { Used in } \mathrm{m}^{3}\end{array}$} & \multirow{2}{*}{$\begin{array}{l}\text { GHG Metric for Onsite } \\
\text { Non Potable Water Use } \\
\text { in }\left(\mathrm{kgCO}_{2 \mathrm{e}} / \mathrm{m}^{3}\right)\end{array}$} \\
\hline & 1. Extract and Divert & 2. Place into Storage & 3. Conveyance & 4. Treatment & 5. Distribution & & & & & & \\
\hline \multicolumn{12}{|c|}{ Medical Facility Case Study (MFCS) } \\
\hline $\begin{array}{l}\text { Desalinated potable } \\
\text { water use onsite as } \\
\text { makeup water }\end{array}$ & \multicolumn{5}{|c|}{ These steps are included in the final emission factor generated by $\operatorname{EAD}[70]$} & 3 & Equation (14) & Equation (7) & 15.40 [20] & $\begin{array}{l}\text { Make up water used } \\
\text { onsite monitored by } \\
\text { EMCS records }\end{array}$ & \multirow{2}{*}{ Equation (11) } \\
\hline $\begin{array}{l}\text { Air conditioning } \\
\text { condensate water } \\
\text { (A/C CW) }\end{array}$ & \multicolumn{5}{|c|}{ No emission other than scope 2 below } & 3 & Equation (15) & Nil & Nil & $\begin{array}{l}\text { Onsite generated and } \\
\text { used and monitored } \\
\text { by EMCS records }\end{array}$ & \\
\hline $\begin{array}{l}38 \% \text { makeup } \\
\text { desalinated water } \\
\text { and } 62 \% \text { condensate } \\
\text { water (AC CW) for } \\
\text { both WFs and LI use }\end{array}$ & $\begin{array}{l}\text { Nil because the } \\
\text { condensate water is } \\
\text { generated regardless of } \\
\text { condensate water } \\
\text { recycling or not }\end{array}$ & $\begin{array}{l}\text { Gravity fed into raw water storage } \\
\text { tank }\end{array}$ & $\begin{array}{l}\text { AC CW } \\
\text { conveyed to } \\
\text { treatment plant } \\
\text { by pump (P1)- } \\
\text { see Figure A1 in } \\
\text { Appendix A }\end{array}$ & $\begin{array}{l}\text { AC CW treated } \\
\text { to secondary and } \\
\text { tertiary } \\
\text { treatment for } \\
\text { WFs and LI reuse }\end{array}$ & $\begin{array}{l}\text { ACCW } \\
\text { distributed to } \\
\text { point of delivery } \\
\text { onsite to WFs } \\
\text { and LI }\end{array}$ & 2 & Equation (13) & Equation (5) & Equation (6) & $\begin{array}{l}\text { Included in scope } 3 \\
\text { above }\end{array}$ & \\
\hline \multicolumn{12}{|l|}{ Baseline Scenario 2 (S2) } \\
\hline $\begin{array}{l}\text { Desalinated potable } \\
\text { water use onsite as } \\
\text { makeup water }\end{array}$ & $\begin{array}{l}\text { Included in scope } 3 \\
\text { below }\end{array}$ & $\begin{array}{l}\text { Pumped to storage. Refer to } \\
\text { Figure A1 in Appendix A }\end{array}$ & \multirow{2}{*}{$\begin{array}{l}\begin{array}{l}\text { Desalinated } \\
\text { water conveyed } \\
\text { to treatment } \\
\text { plant by pump } \\
\text { (P3) }\end{array} \\
\text { AD [70] }\end{array}$} & $\begin{array}{l}\text { Secondary and } \\
\text { tertiary } \\
\text { treatment for } \\
\text { WFs only }\end{array}$ & \multirow[t]{2}{*}{$\begin{array}{l}\text { Deasilated water } \\
\text { distributed to } \\
\text { point of delivery } \\
\text { onsite to WFs } \\
\text { and LI }\end{array}$} & 2 & Equation (13) & Equation (5) & Equation (6) & $\begin{array}{l}\text { Make up water used } \\
\text { onsite monitored by } \\
\text { EMCS records }\end{array}$ & \multirow[t]{2}{*}{ Equation (11) } \\
\hline $\begin{array}{l}\text { Desalinated potable } \\
\text { water use }\end{array}$ & \multicolumn{3}{|c|}{ These steps are included in the final emission factor generated by EAD [70] } & & & 3 & Equation (14) & Equation (7) & $15.40[20]$ & $\begin{array}{l}\text { Included in scope } 2 \\
\text { above }\end{array}$ & \\
\hline \multicolumn{12}{|c|}{ Proposed Research Project Scenario 3 (PRP S3) } \\
\hline \multirow[b]{2}{*}{$\begin{array}{l}\text { Reverse Osmosis } \\
\text { Reject Water } \\
\text { (RO RW) }\end{array}$} & \multirow{2}{*}{$\begin{array}{l}\text { Nil because the reject } \\
\text { water is genenareded } \\
\text { regardless of reject water } \\
\text { recycling or not }\end{array}$} & \multirow{2}{*}{$\begin{array}{l}\text { Pumped to raw A/C CW storage tank. } \\
\text { Assume a transfer pump consuming } \\
0.11 \mathrm{kWh} / \text { /ay (P8) Figure A1 and } \\
\text { Table A1 in Appendix A. }\end{array}$} & \multirow{2}{*}{\multicolumn{3}{|c|}{$\begin{array}{l}\text { Mixed with } \mathrm{A} / \mathrm{C} C W \text { in raw condensate water tanks (no } \\
\text { extra power needed) }\end{array}$}} & 3 & Equation (15) & Nil & Nil & \multirow[b]{2}{*}{ Equation (4) in [6] } & \multirow{7}{*}{ Equation (11) } \\
\hline & & & & & & 2 & Equation (13) & $\begin{array}{l}\text { Part of Equation } \\
\text { (5) below }\end{array}$ & $\begin{array}{l}\text { Part of } \\
\text { Equation (6) } \\
\text { below }\end{array}$ & & \\
\hline \multirow[b]{2}{*}{$\begin{array}{l}\text { Food waste Effluent } \\
\text { wastewater (FEW) [6] }\end{array}$} & \multirow[b]{2}{*}{$\begin{array}{l}\text { Dehydrator power }(13 \\
\mathrm{kWh} \text { per day) }[6]\end{array}$} & \multirow[b]{2}{*}{$\begin{array}{l}\text { Pumped to storage. Assume a small } \\
\text { transfer pump (power unknown) }\end{array}$} & \multirow{2}{*}{\multicolumn{3}{|c|}{$\begin{array}{l}\text { Mixed with } \mathrm{A} / \mathrm{C} \mathrm{CW} \text { in raw condensate water tanks (no } \\
\text { extra power needed) [6] }\end{array}$}} & 3 & Equation (15) & Nil & Nil & & \\
\hline & & & & & & 2 & Equation (13) & $\begin{array}{l}\text { Part of Equation } \\
\text { (5) below }\end{array}$ & $\begin{array}{l}\text { Part of } \\
\text { Equation (6) } \\
\text { below }\end{array}$ & $\begin{array}{l}\text { Estimate }(85 \%-95 \%) \\
\text { of food weight [6] }\end{array}$ & \\
\hline \multirow[t]{2}{*}{$\begin{array}{l}\text { Air conditioning } \\
\text { condensate water } \\
\text { (A/C CW) }\end{array}$} & \multirow[t]{2}{*}{$\begin{array}{l}\text { Nil because the } \\
\text { condensate water is } \\
\text { generated regardless of } \\
\text { condensate water } \\
\text { recycling or not }\end{array}$} & \multirow[t]{2}{*}{$\begin{array}{l}\text { Gravity fed into raw water } \\
\text { storage tank }\end{array}$} & $\begin{array}{l}\text { ACCW } \\
\text { conveyed to } \\
\text { treatment plant } \\
\text { by pump (P1) } \\
\text { Figure A1 and } \\
\text { Table A1 in } \\
\text { Appendix A } \\
\end{array}$ & $\begin{array}{l}\text { ACCW treated } \\
\text { to secondary and } \\
\text { tertiary } \\
\text { treatment for } \\
\text { WFs and LI }\end{array}$ & $\begin{array}{l}\text { ACCW } \\
\text { distributed to } \\
\text { point of delivery } \\
\text { onsite for WFs } \\
\text { and LI use }\end{array}$ & 2 & Equation (13) & Equation (5) & Equation (6) & $\begin{array}{l}\text { Onsite generated } \\
\text { used and monitored } \\
\text { by EMCS records }\end{array}$ & \\
\hline & & & No emission other & than scope 2 above & & 3 & Equation (15) & Nil & Nil & $\begin{array}{l}\text { Onsite generated } \\
\text { monitored by EMCS } \\
\text { records }\end{array}$ & \\
\hline $\begin{array}{l}\text { Fire Sprinkler Pump } \\
\text { Test Water (FSPTW) }\end{array}$ & $\begin{array}{l}\text { Nil because the water is } \\
\text { used for testing the fire } \\
\text { pumps regardless of fire } \\
\text { sprinkler pump test } \\
\text { water recycling or not. }\end{array}$ & $\begin{array}{l}\text { Conveyed to storage through existing } \\
\text { pump }\end{array}$ & $\begin{array}{l}\text { Mixed with } \mathrm{A} / \mathrm{CC} \\
\text { extra power neede }\end{array}$ & $\begin{array}{l}\text { W in raw condensate } \\
\text { d) }\end{array}$ & water tanks (no & 3 & Equation (15) & Nil & Nil & $\begin{array}{l}\text { Equation (1) in [6] } \\
\text { Equation (2) in [6] } \\
\text { Equation (3) in }[6]\end{array}$ & \\
\hline
\end{tabular}




\section{References}

1. Köppen and Geiger. World Maps of Köppen-Geiger Climate Classification. Available online: http: //koeppen-geiger.vu-wien.ac.at/present.htm (accessed on 6 February 2017).

2. National Centre of Meteorology. Climate Yearly Report of AD 2003-2016. 2017. Available online: http://www.ncm.ae/en/climate-reports-yearly.html?id=26 (accessed on 6 February 2017).

3. Pizzi, N.G. Water Treatment: Principles and Practices of Water Supply Operations, 4th ed.; American Water Works Association: Denver, CO, USA, 2010.

4. $\quad$ Mitchell, K. From Increasing Supply to Managing Demand', Al Manakh 2: Cont'd; Reisz, T., Ed.; Stichting Archis: Amsterdam, The Netherlands, 2009.

5. World Bank. Adaptation to a Changing Climate in the Arab Countries: A Case for Adaptation Governance and Leadership in Building Climate Resilience; Verner, D., Ed.; World Bank: Washington, DC, USA, 2012.

6. Seguela, G. Implementation and Evaluation of an Outdoor Water Conservation Strategy for Hospital Decarbonisation in an Arid Climate. Ph.D. Thesis, Cardiff Metropolitan University, Cardiff, UK, 2018.

7. Cardno. Greywater/Condensate Water Risk Assessment Report; Medical Facility: Abu Dhabi, UAE, 2014.

8. Creswell, J.W.; Creswell, J.D. Research and Design Qualitative, Quantitative and Mixed Methods Approaches; Sage Publication: Thousand Oaks, CA, USA, 2018.

9. Healthcare Environmental Resource Center. Facilities Management-Water Conservation. Available online: http://www.hercenter.org/facilitiesandgrounds/waterconserve.cfm (accessed on 5 July 2015).

10. Abu Dhabi Distribution Company. Water and Energy Tariffs 2017. Available online: https://www.addc.ae/enUS/residential/Documents/02-English.pdf (accessed on 1 January 2018).

11. Ali, S.E.; Alsaman, A.S.; Harby, K.; Askalany, A.A.; Refaat Diab, M.; Ebrahim Yakoot, S.M. Recycling Brine Water of Reverse Osmosis Desalination Employing Adsorption Desalination: A Theoretical Simulation. Desalination. Available online: http://dx.doi.org/10.1016/j.desal.2016.12.0020011-9164 (accessed on 28 March 2017).

12. Shahid, S.A.; Abdelfattah, M.A.; Othman, Y.; Kumar, A.; Taha, F.K.; Kelley, J.A.; Wilson, M.A. Innovative Thinking for Sustainable Use of Terrestrial Resources in AD Emirate Through Scientific Soil Inventory and Policy Development. In Developments in Soil Classification, Land Use Planning and Policy Implications; Shahid, S.A., Taha, F.K., Abdelfattah, M.A., Eds.; Springer: Berlin/Heidelberg, Germany, 2013; pp. 3-49.

13. Pacia, D.; Yeh, D. Adaptation to Climate for Water Utilities. In Water Reclamation and Sustainability; Ahuja, S., Ed.; Elsevier: San Diego, CA, USA, 2014; pp. 19-56.

14. Balfaqih, H.; Al-Nory, M.T.; Nopiah, Z.M.; Saibani, N. Environmental and economic performance assessment of desalination supply chain. Desalination 2017, 406, 2-9. [CrossRef]

15. Murad, A.; Nuaimiu, H.; Hammadi, M. Comprehensive Assessment of Water Resources in the United Arab Emirates (UAE). Water Resour. Manag. 2007, 21, 1449-1463. [CrossRef]

16. Ministry of Energy UAE. 3rd National Communication under the United Nations Framework Convention on Climate Change. Available online: https://www.moenr.gov.ae/assets/b8502605/uae-3rd-nationalcommunication-report.aspx (accessed on 2 October 2017).

17. Almaeeni, W.; Dawood, M.; I-Tsung, T. Strategic Water Reserve's Effect on the Water Supply System in AD: A System Dynamics Approach. International Council on Systems Engineering; Wiley online Library: Hoboken, NJ, USA, 2014; Volume 24, pp. 759-774.

18. Regulation Supervision Bureau. Technical Report. AD: RSB. Available online: http://rsb.gov.ae/en/ publications/detail/technical-report-2015 (accessed on 27 April 2017).

19. Dawoud, M.A. Strategic Water Reserve: New Approach for Old Concept in GCC Countries; Environment Agency: Bristol, UK, 2008.

20. Ministry of Environment and Water. United Arab Emirates Water Conservation Strategy. Available online: http://extwprlegs1.fao.org/docs/pdf/uae147095.pdf (accessed on 6 February 2017).

21. Cisneros, B.J. Water Recycling and Reuse: An Overview. In Water Reclamation and Sustainability, 1st ed.; Ahuja, S., Ed.; Elsevier: San Diego, CA, USA, 2014; pp. 431-454.

22. XE. Xenon Laboratories. Currency Converter Rate. Available online: https://www.xe.com/currencyconverter/ convert/?Amount=1\&From=AED\&To=GBP (accessed on 10 September 2017).

23. Heid, J. The Paradox of Sustainability and AD, Al Manakh 2: Cont'd; Reisz, T., Ed.; Stichting Archis: Amsterdam, The Netherlands, 2009; pp. 118-119. 
24. World Bank. Seawater and Brackish Water Desalination in the Middle East, North Africa and Central Asia. Available online: http://documents.worldbank.org/curated/en/813191468191928325/pdf/ 335150v70Seawater0annex060cyprus.pdf (accessed on 25 February 2016).

25. Einav, R.; Harussi, K.; Perry, D. The footprint of the desalination processes on the environment. Desalination 2003, 152, 141-154. [CrossRef]

26. Einav, R.; Lokiec, F. Environmental aspects of a desalination plant in Ashkelon. Desalination 2003, 156, 79-85. [CrossRef]

27. Regulation Supervision Bureau. Supporting the AD Economic Vision 2030. AD: RSB. Available online: http://rsb.gov.ae/assets/documents/770/vision2030may2013.pdf (accessed on 24 January 2017).

28. Seguela, G.; Littlewood, J.R.; Karani, G. Eco-engineering strategies for soil restoration and water conservation: Investigating the application of soil improvements in a semi-arid climate in a Medical Facility Case Study. J. Ecol. Eng. 2017, 121, 53-64. [CrossRef]

29. Environment Agency-AD. The Water Resources Management Strategy for the Emirates of AD $2014-2018$. AD: EAD. Available online: https://www.ead.ae/Documents/PDF-Files/Executive-Summary-of-TheWater-Resources-Management-Strategy-for-the-Emirate-of-Abu-Dhabi-2014-2018-Eng.pdf (accessed on 30 January 2014).

30. Jarrar, A. Utilization of Treated Sewage Effluent for Landscape Irrigation in Abu Dhabi City. In Proceedings of the Future Landscape \& Public Realm Conference, Abu Dhabi, UAE, 13 November 2017.

31. International Energy Agency. Water Energy Nexus; OECD/IEA: Paris, France. Available online: https://www. iea.org/publications/freepublications/publication/WorldEnergyOutlook2016ExcerptWaterEnergyNexus. pdf (accessed on 28 March 2018).

32. Ferrell, L.; Sarrouh, S.; Walski, T.; Elliott, T.; Deavenport, S. Technology measures for energy efficiency. In Energy Management for Water Utilities; Dufresne, L., Ferrell, L., Eds.; American Water Works Association: Denver, CO, USA, 2016; pp. 59-96.

33. Shashua-Bar, L.; Pearlmutter, D.; Evyatar, E. The cooling efficiency of urban landscape strategies in a hot dry climate. J. Landsc. Urban Plan. 2009, 92, 179-186. [CrossRef]

34. Ferguson, B.K. Water conservation methods in urban LI: An exploratory overview. J. Am. Water Resour. Assoc. 2007, 23, 147-152. Available online: https://www.researchgate.net/publication/229481559 (accessed on 20 January 2017). [CrossRef]

35. The Climate Registry. GENERAL Reporting Protocol Version 2.1. Available online: https://www. theclimateregistry.org/wp-content/uploads/2014/11/General-Reporting-Protocol-Version-2.1.pdf (accessed on 13 April 2017).

36. Nair, S.; George, B.; Malano, H.M.; Arora, M.; Nawarathna, B. Water-Energy Greenhouse Gas Nexus of Urban Water Systems: Review of Concepts, State of-Art and Methods. J. Resour. Conserv. Recycl. 2014, 89, 1-10. Available online: https://doi.org/10.1016/j.resconrec.2014.05.007 (accessed on 18 January 2018). [CrossRef]

37. Griffiths-Sattenspiel, B.; Wilson, W. The Carbon Footprint of Water. Portland: A River Network Report. Available online: https://albertawater.com/docs/CarbonFootprintofWater.pdf (accessed on 6 February 2017).

38. California Public Utilities Commission. Embedded Energy in Water Studies-Study 2: Water Agency and Function Component Study and Embedded Energy Water Load Profiles. Available online: Ftp://ftp.cpuc.ca. gov/gopher-data/energy\%20efficiency/Water\%20Studies\%201/Study\%201\%20-\%20FINAL.pdf (accessed on 23 January 2016).

39. California Public Utilities Commission. Embedded Energy in Water Studies-Study 1: State-Wide and Regional Water-Energy Relationship. Available online: Ftp://ftp.cpuc.ca.gov/gopher-data/energy\%20efficiency/Water\% 20Studies\%202/Study\%202\%20-\%20FINAL.pdf (accessed on 23 January 2016).

40. United Nations. Status of Ratification of the UN Framework Convention on Climate Change. Available online: https://unfccc.int/sites/default/files/resource/docs/cop3/inf02.pdf (accessed on 3 February 2017).

41. United Nations. UN Framework Convention on Climate Change. Climate Change: Impacts, Vulnerabilities, and Adaptation in Developing Countries. Available online: https://unfccc.int/resource/docs/publications/ impacts.pdf (accessed on 3 February 2017).

42. The Climate Registry. Water Energy GHG Guidance. Available online: https://www.theclimateregistry.org/ wp-content/uploads/2015/12/Water-Energy-GHG-Guidance-December-2015.pdf (accessed on 13 April 2017).

43. Fay, M.; Hallegatte, S.; Vogt-Schilb, A.; Rozenberg, R.; Narloch, U.; Kerr, T. Decarbonizing Development: Three Steps to a Zero-Carbon Future; World Bank: Washington, DC, USA, 2015. 
44. Intergovernmental Panel on Climate Change. Climate Change 2014: Synthesis Report; United Nations Environment Programme (UNEP) and the World Meteorological Organization (WMO): Geneva, The Netherlands, 2014.

45. Environment Agency-AD. AD State of Environment Report 2017. AD: EAD. Available online: https://www.ead.ae/ Publications/Abu\%20Dhabi\%20State\%20of\%20Environment\%20Report\%202017/EAD-full-report.pdf (accessed on 28 March 2018).

46. Walsh, B.P.; Murray, N.S.; O'Sullivan, D.T.J. The Water Energy Nexus, an ISO50001 Water Case Study and The Need for a Water Value System. J. Water Resour. Ind. 2015, 10, 15-28. Available online: https://doi.org/10.1016/j.wri.2015.02.001 (accessed on 18 January 2018). [CrossRef]

47. International Standard Organization. ISO 14046:2016. Environmental Management Water Footprint Principles, Requirements and Guidelines; ISO: Geneva, The Netherlands, 2016.

48. International Standard Organization. ISO 50001:2017. Energy Management Systems. Requirements with Guidance for Use; ISO: Geneva, The Netherlands, 2017.

49. Ruddell, B.L.; Richard, R.; Elizabeth, A. Adams Generalizing ecological, water and carbon footprint methods and their worldview assumptions using Embedded Resource Accounting. Water Resour. Ind. 2013, 1-2, 77-90. [CrossRef]

50. World Resources Institute \& World Business Council for Sustainable Development. The Greenhouse Gas Protocol: Technical Guidance for Calculating Scope Three Emissions, Version 01; WRI \& WBCSD: Geneva, The Netherlands, 2013.

51. Seguela, G.; Littlewood, J.R.; Karani, G. A study to Assess Non-Potable water Sources for Reducing energy Consumption in a Medical Facility Case Study. Energy Procedia 2017, 134, 797-806. Available online: https://doi.org/10.1016/j.egypro.2017.09.532 (accessed on 24 October 2017). [CrossRef]

52. Seguela, G.; Littlewood, J.R.; Karani, G. Onsite food Waste Processing as an Opportunity to Conserve Water in a Medical Facility Case Study, AD. Energy Procedia 2017, 111, 548-557. Available online: http: //dx.doi.org/10.1016/j.egypro.2017.03.217 (accessed on 27 March 2017). [CrossRef]

53. Abu Dhabi Municipality. Irrigation Systems Operation and Maintenance, Parks and Recreation Facilities Division: AD, 2C Section 02800; ADM: Chicago, IN, USA, 2013; p. 5.

54. Dufresne, L.; Ferrell, L. Energy Management for Water Utilities; American Water Works Association: Denver, CO, USA, 2016.

55. Elliott, T.; Zeier, B.; Xagoraraki, I. Energy Use at Wisconsin's Drinking Water Facilities; Energy Centre: Madison, WI, USA, 2003. Available online: https://www.seventhwave.org/sites/default/files/222-1.pdf (accessed on 3 February 2018).

56. WRI \& WBCSD. World Resources Institute \& World Business Council for Sustainable Development. A Corporate Accounting and Reporting Standard; WRI \& WBCSD: Geneva, The Netherlands, 2015.

57. International Standard Organization. Greenhouse Gases- Part 1: Specification with Guidance at the Organization Level for Quantitation and Reporting of Greenhouse Gas Emissions and Removals; ISO: Geneva, The Netherlands, 2006.

58. International Standard Organization. Greenhouse Gases- Part 2: Specification with Guidance at the Project Level for Quantitation, Monitoring and Reporting of Greenhouse Gas Emission Reductions or Removal Enhancements; ISO: Geneva, The Netherlands, 2006.

59. Intergovernmental Panel on Climate Change. IPCC Guidelines for National Greenhouse Gas Inventories; United Nations Environment Programme (UNEP) and the World Meteorological Organization (WMO): Geneva, The Netherlands, 2006.

60. Kay, M.; Hatcho, N. Small-Scale Pumped Irrigation: Energy and Cost; Food and Agriculture Organization of the United Nations (FAO): Rome, Italy, 1992.

61. Forrest, N.; Williams, E. Life Cycle Environmental Implications of Residential Swimming Pools, Environmental Science Technology; William, E., Ed.; ACS Publications: Washington, DC, USA, 2010; Volume 23, pp. 147-152.

62. Gallion, T.; Harrison, T.; Hulverson, R.; Hristovski, K. Estimating Water, Energy and Carbon Footprints of Residential Swimming Pools. In Water Reclamation and Sustainability, 1st ed.; Ahuja, S., Ed.; Elsevier: San Diego, CA, USA, 2014; pp. 343-359.

63. Conway, D.; Rothausen, S.G.S.A. Greenhouse-Gas Emissions from Energy Use in the Water Sector; Nature Ology Advance Online Publication: London, UK, 2011. 
64. Cheng, C.L. Study of the inter-relationship between water use and energy conservation for a building. Energy Build. 2002, 34, 261-266. [CrossRef]

65. Chiu, Y.-R.; Liaw, C.-H.; Chen, L.-C. Optimizing rainwater harvesting systems as an innovative approach to saving energy in hilly communities. Renew. Energy 2009, 34, 492-498. [CrossRef]

66. Retamal, M.; Glassmire, J.; Abeysuriya, K.; Turner, A.; White, S. The Water-Energy Nexus: Investigation into the Energy Implications of Household Rainwater Systems; University of Technology (UTS): Sydney, Australia. Available online: https:/opus.lib.uts.edu.au/bitstream/10453/20456/4/retamaletal2009waterenergynexus.pdf (accessed on 16 January 2018).

67. Vieira, A.S.; Beal, C.D.; Ghisi, E.; Steward, R.A. Energy Intensity of Rainwater Systems: A Review. J. Renew. Sustain. Energy Rev. 2014, 34, 225-242. [CrossRef]

68. Ward, S.; Butler, D.; Menon, F.A. Benchmarking energy consumption and $\mathrm{CO}_{2}$ emissions from rainwater-harvesting systems: An improved method by proxy. Water Environ. 2012, 26, 184-190. [CrossRef]

69. Reygadas, F. User Compliance, Field Efficacy, and Greenhouse Gas Emissions of an Ultraviolet Water Disinfection System and Other Drinking Water Treatment Alternatives for Rural Households in Mexico. Ph.D. Thesis, University of California, Berkeley, CA, USA, 2014.

70. Environment Agency-AD. Greenhouse Gas Inventory for AD Emirate. AD: EAD. Available online: https: //www.ead.ae/Documents/PDF-Files/AD-Greenhouse-gas-inventory-Eng.pdf (accessed on 30 January 2014).

71. International Standard Organization. ISO/TR 14069:2013 Greenhouse Gases-Quantification and Reporting of Greenhouse Gas Emissions for Organizations-Guidance for the Application of ISO 14064-1; ISO: Geneva, The Netherlands, 2013.

72. Central Bank of the United Arab Emirates. United Arab Emirates Interest Rate. Available online: https: //tradingeconomics.com/united-arab-emirates/interest-rate (accessed on 10 September 2017).

73. Central Bank of the United Arab Emirates. United Arab Emirates Inflation Rate. Available online: https://tradingeconomics.com/united-arab-emirates/inflation-cpi (accessed on 6 February 2017).

74. Letterman, R.D.; Driscoll, C.T.; Haddad, M.; Hau, H.A. Limestone Bed Contactors for Control of Corrosion at Small Water Utilities; National Service Center for Environmental Publications (NSCEP): Washington, DC, USA, 1986.

75. Regulation Supervision Bureau. New Water and Electricity Tariffs Structure. AD: RSB. Available online: http://rsb.gov.ae/en/sector/new-water-and-electricity-tariffs-structure (accessed on 9 January 2016).

76. Caperhart, B.; Turner, W.C.; Kennedy, W.J. Guide to Energy Management, 8th ed.; The Fairmont Press: Lilburn, GA, USA, 2008.

77. Parker, S.A.; Walker, B.K. Boilers and Fired Systems. In Energy Management Handbook, 8th ed.; Doty, S., Turner, W.C., Eds.; The Fairmont Press: Lilburn, GA, USA, 2008; pp. 91-129.

78. Deyong, C. Economic Analysis and Life Cycle Costing. In Guide to Energy Management, 5th ed.; Caperhart, B., Turner, W.C., Kennedy, W.J., Eds.; The Fairmont Press: Lilburn, GA, USA, 2008; pp. 133-174.

79. Pratt, D. Economic Analysis. In Energy Management Handbook, 8th ed.; Doty, S., Turner, W.C., Eds.; The Fairmont Press: Lilburn, GA, USA, 2008; pp. 47-90.

80. Doty, S.; Turner, W.C. Energy Management Handbook, 8th ed.; The Fairmont Press: Lilburn, GA, USA, 2013.

81. Mackey, E.D.; Cushing, R.; Crozes, G.F. Practical Aspects of UV Disinfection; American Water Works Association (AWWA) Research Foundation: Denver, CO, USA, 2001.

(C) 2020 by the authors. Licensee MDPI, Basel, Switzerland. This article is an open access article distributed under the terms and conditions of the Creative Commons Attribution (CC BY) license (http://creativecommons.org/licenses/by/4.0/). 